\title{
Archaeological Investigations at the Ikirahak Site Raise Questions Concerning Taltheilei Land Use in Southern Nunavut
}

\author{
Don H. Butler, ${ }^{1,2}$ Sean J. Pickering ${ }^{1}$ and Peter C. Dawson ${ }^{1}$
}

(Received 14 May 2018; accepted in revised form 20 August 2019)

\begin{abstract}
We report a new Taltheilei site-type found off the west coast of Hudson Bay in southern Nunavut. The Taltheilei is an archaeological culture that existed in the Barrenlands of the central Canadian Subarctic between 2600 and 300 years ago. Their land use strategies were tethered to the seasonal migrations of the Beverly and Qamanirjuaq caribou herds throughout tundra and forest landscapes. Tundra-based sites are typically interpreted as short-lived summer camps, but our discovery of three unique pit-house sites on the shores of Maguse Lake raises new questions concerning diversity in Taltheilei tundra land use. Architectural, faunal, lithic, and geoarchaeological data recovered from the Ikirahak site (JjKs-7) support the hypothesis that Taltheilei groups were extending their tundra stays into the fall. We report the evidence from four excavated pit-house features. Terraced platforms along the internal perimeters of these houses suggest they were designed for cold season use. The faunal assemblage is dominated by caribou remains. Higher relative frequencies of appendicular elements suggest a focus on secondary butchering. A large fraction of the faunal assemblage is highly fragmented and calcined, which is consistent with heavy processing and the use of bone as an alternative fuel source. Higher frequencies of lithic debris around dwelling floor perimeters are suggestive of maintenance activities. Multi-element concentrations in dwelling and site-wide sediments also show that hearth refuse was dumped outside. These findings seem to reflect longer tundra occupations during fall, a land use strategy that was likely guided by Qamanirjuaq herd behaviour specific to the Maguse Lake area, fall hunting and processing goals, and ecologically couched mobility logistics. As just four pit-houses from one Taltheilei camp have been investigated to date, our understanding of these places within Taltheilei worlds and northern socio-ecologies is currently limited. Further research at Ikirahak, the other Maguse Lake pit-house sites, and at other caribou water crossings on the tundra of the Qamanirjuaq caribou range is needed to support or refute our hypotheses.
\end{abstract}

Key words: archaeology; Taltheilei culture; Nunavut; Barrenlands; land use; mobility; seasonality; caribou hunting

RÉSUMÉ. Nous signalons un nouveau site de type taltheilei trouvé sur la côte ouest de la baie d'Hudson, dans le sud du Nunavut. La culture taltheilei est une culture archéologique qui a existé dans les landes de la zone subarctique centrale canadienne il y a de cela 2600 à 300 ans. Les stratégies d'utilisation des terres de cette culture étaient rattachées aux migrations saisonnières des hardes de caribous de Beverly et de Qamanirjuaq dans la toundra et la forêt. De manière générale, les sites trouvés dans la toundra sont interprétés comme des campements d'été de courte durée. Cependant, notre découverte de trois sites uniques de maisons semi-souterraines sur les rives du lac Maguse soulève de nouvelles questions au sujet de la diversité de l'utilisation de la toundra par les Taltheilei. Les données architecturales, fauniques, lithiques et géoarchéologiques recueillies au site d'Ikirahak soutiennent l'hypothèse selon laquelle les groupements de Taltheilei occupaient la toundra jusqu'à l'automne. Nous signalons des preuves en provenance de quatre aménagements de maisons semi-souterraines. Le long du périmètre interne de ces maisons, les plateformes en terrasses suggèrent qu'elles étaient conçues pour servir pendant la saison froide. Des restes de caribous dominent l'assemblage faunique. Des fréquences relatives plus élevées d'éléments appendiculaires laissent entrevoir que le dépeçage secondaire y occupait une grande place. Une grande fraction de l'assemblage faunique est fortement fragmentée et calcinée, ce qui correspond à une transformation importante et à l'utilisation des os comme source de combustible. Les grandes fréquences de débris lithiques entourant le périmètre des planchers d'habitations suggèrent des activités de maintenance. Les concentrations d'éléments multiples dans les sédiments des habitations et de l'ensemble du site indiquent également que les déchets des âtres étaient jetés à l'extérieur. Ces constatations laissent entrevoir de plus longues occupations de la toundra à l'automne, une stratégie d'utilisation des terres vraisemblablement guidée par le comportement propre à la harde de Qamanirjuaq dans la région du lac Maguse, par la chasse automnale et par les objectifs de transformation, de même que par la logistique de la mobilité en termes écologiques. Puisque seulement quatre maisons semi-souterraines d'un seul campement taltheilei ont été étudiées jusqu'à maintenant, nous comprenons toujours peu de choses au sujet de ces endroits dans le monde des Taltheilei et des socioécologies nordiques. Il y a lieu de pousser les recherches plus loin à Ikirahak, là où se trouvent les autres sites de maisons semi-souterraines du lac Maguse, ainsi qu'à d'autres passages de franchissement de l'eau sur la toundra du parcours des caribous de Qamanirjuaq afin de confirmer ou de réfuter nos hypothèses.

\footnotetext{
${ }^{1}$ University of Calgary Department of Anthropology and Archaeology, 2500 University Drive NW, Calgary, Alberta T2N 1N4, Canada

${ }^{2}$ Corresponding author: dhbutler@ucalgary.ca

(C) The Arctic Institute of North America
} 
Mots clés : archéologie; culture taltheilei; Nunavut; landes; utilisation des terres; mobilité; saisonnalité; chasse au caribou

Traduit pour la revue Arctic par Nicole Giguère.

\section{INTRODUCTION}

This paper summarizes archaeological findings from the Ikirahak site (JjKs-7) in southern Nunavut (Fig. 1: a). Recovered artifacts belong to the Taltheilei archaeological culture, which arrived in the Barrenland region of the central Canadian subarctic around 2600 years ago (Gordon, 2005). Over 700 Taltheilei sites have been documented throughout the tundra, treeline, and boreal forest environments spanning the Beverly and Qamanirjuaq caribou ranges (Fig. 1) (Nash, 1970; Gordon, 1975, 1996; Petch, 1992; Petch et al., 1997). Archaeological evidence paired with analogy drawn from the 18th century Chipewyan, the direct descendents of the Taltheilei, reveals a land-use strategy tightly connected to the seasonal rounds of these herds. Spring was spent moving out of winter forest territories, first to treeline camps, then into northern tundra landscapes. During summer, small highly mobile groups struck out across the tundra in search of dispersed, quickly moving herds. They gathered at treeline camps during the late summer to hunt aggregated herds, after which they settled into the deep forest for winter (Gordon, 1975, 1976, 1981, 1996, 2005; Burch and Blehr, 1991; Schwimmer et al., 1998). Taltheilei people are thought to have lived this way for about 2000 years. This adaptation deteriorated after European contact and throughout the historic period, with many Chipewyan people settling into the forest to participate in trapping and trading economies (Gordon, 1996).

Our surveys of the Maguse Lake area in the Qamanirjuaq Range led to the discovery of three unusual sites that do not fit neatly within this model of Taltheilei land use and mobility (Kuuvik 1, JiKu-1; Kuuvik 2, JiKu-2; Ikirahak, JjKs-7; Fig. 1: a and b) (Gordon, 1996; Dawson et al., 2008a, b, 2009, 2010; Pickering, 2012; Butler and Dawson, 2013, 2018; Butler et al., 2018). Tundra sites are expected to be small ephemeral summer camps. In contrast, the sites we documented on the tundra around Maguse Lake are distinctly characterized by the presence of several pit-houses. Seven pit-house depressions were recorded at Kuuvik 1, while three were mapped at Kuuvik 2. Originally documented by J.L. Giddings in 1953 during preliminary archaeological surveys, Ikirahak is the largest of these sites, with 10 pit-houses ordered in a linear array parallel to the Ikirahak Island shoreline (Giddings, 1956; Dawson et al., 2008a, b). No other pit-house sites are known to exist among the over 700 Taltheilei sites found in the Beverly and Qamanirjuaq Ranges. Maguse Lake sites do not appear to be small, ephemeral summer encampments. They also provide rare opportunities to investigate the use of space at the dwelling scale. Our work in this region of Nunavut raises new questions concerning diversity in Taltheilei land use strategies, specifically in terms of residential mobility, seasonality, and hunting on the tundra in the Maguse Lake area.

Dwelling architecture, faunal remains, lithic assemblages, anthrosediments, and ethnohistoric data offer insight into these topics. We interpret our findings, the first of their kind recovered from Taltheilei pit-house contexts, as reflections of somewhat longer tundra occupations during fall. Considering all currently available data, we hypothesize that this style of land use is an adaptation among particular eastern Taltheilei groups to tundra ecosystems in the Maguse Lake area. It seems to represent a focus on intercepting Qamanirjuaq herds during fall, and consequently, the logistics involved with resource processing and moving people and resources into the southern forest for winter. Through this paper, we aim to revitalize interest in Taltheilei research-research that will not only serve to further evaluate our hypotheses, but will also shine a brighter light on the diversity of land use strategies practiced by First Nations groups in the Barrenlands.

\section{An Outline of Taltheilei Land Use and Mobility}

The Taltheilei archaeological culture was first identified in the Taltheilei Narrows of Great Slave Lake. It was originally defined by a preference for grey siliceous shale and quartzite tool stone, the production of long lanceolate points with tapered/thinned stems, and sites concentrated at Great Slave Lake and in the drainage basins of the Coppermine, Snare, Black, Lockhart, and Yellowknife Rivers (see MacNeish, 1951; Giddings, 1956; Irving, 1962; McGhee, 1970; Nash, 1970, 1975; Noble, 1971, 1977; Gordon, 1975, 1977a, b; and Wright, 1975 for foundational work on the subject). Based on radiocarbon dates and stylistic changes in projectile points, their tenure in the Beverly and Qamanirjuaq Ranges is divided into Earliest (2600-2450 BP), Early (2450-1800 BP), Middle (1800-1300 BP), and Late (1300-300 BP) periods (Gordon, 1996).

Ethnohistoric analogy drawn from 18th century Chipewyan caribou hunting and land-use practices, Taltheilei site distributions, and ecological observations of modern caribou herd behaviour suggest that Taltheilei settlement and subsistence strategies were closely aligned with predictable caribou migrations. Both people and herds spent the warmer months on the northern tundra and the cold part of the year in the southern forest (Burch and Blehr, 1991; Gordon, 1996). Sub-herds of pregnant cows and yearlings began their northward move out of the forest in April or May. People advanced toward the treeline as early as late March to organize interceptions at caribou water crossings. Small sub-herds spent July moving 


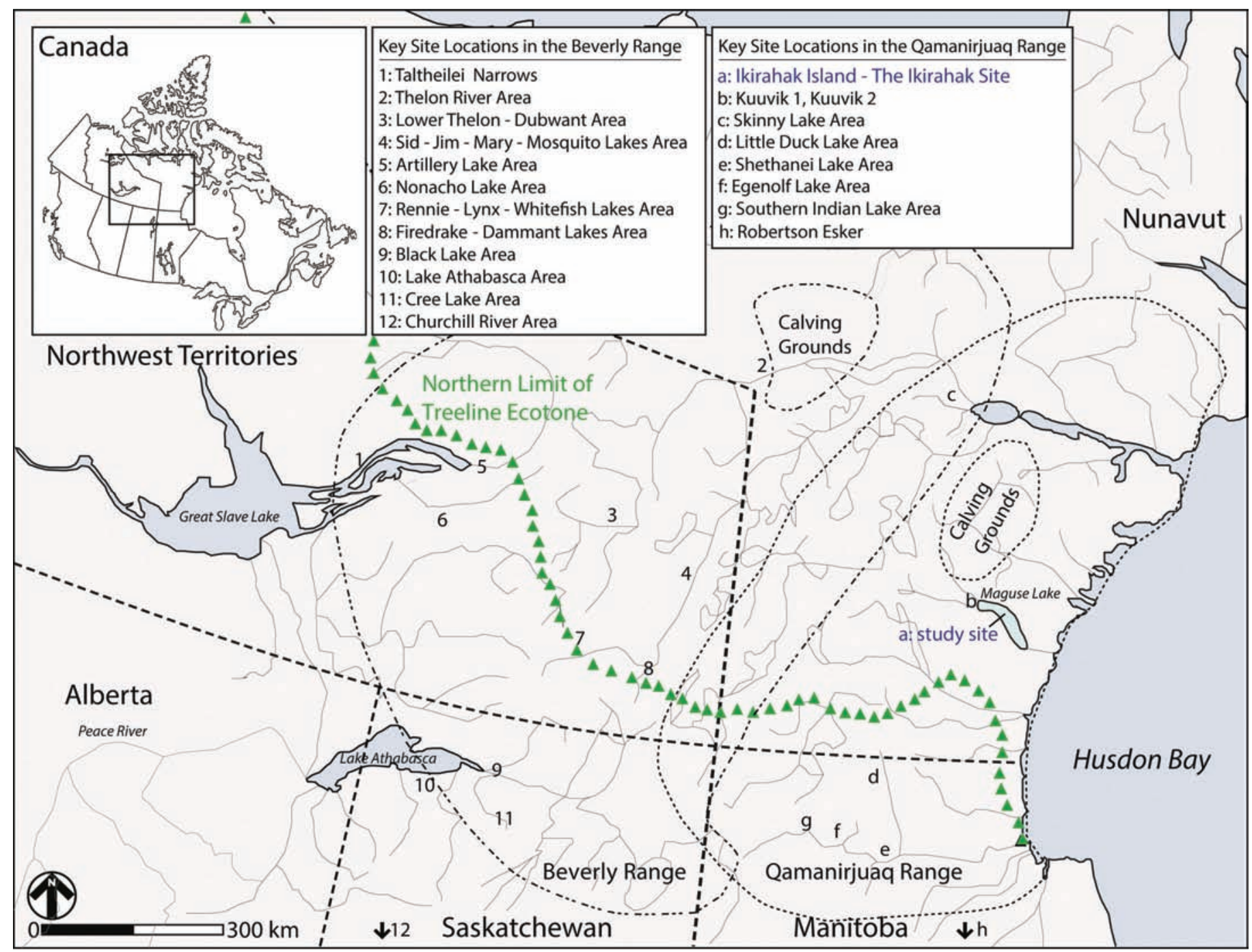

FIG. 1. The Barrenlands and boreal forest of the central Canadian Subarctic. This map highlights key Taltheilei site locations in the Beverly and Qamanirjuaq caribou ranges. The Ikirahak study site is located at "a." Two additional pit-house sites are located at "b."

around on the tundra, with people responding in kind (Parker, 1972; Darby, 1978; Burch and Blehr, 1991; Gordon, 1996; Schwimmer et al., 1998). Sub-herds aggregated and began their migration south during August (Parker, 1972; Darby, 1978). People anticipated this. They moved to the forest edge ahead of herds to position themselves at watercrossing points with the aim of dispatching large numbers of animals. Shortly thereafter, they settled into the sheltered boreal forest for winter. Caribou herds dispersed throughout the southern forest during winter, making a consistent focus on caribou hunting unreliable. In response, people coalesced into larger groups to pool late summer surpluses for the leaner winter months (Parker, 1972; Darby, 1978; Burch and Blehr, 1991; Gordon, 1996).

The scheduling and logistics of travel to and from the tundra were tied to seasonal weather and terrain (Gordon, 1996). Historic and modern data place the onset of cold weather as early as September, with tundra water freeze-up occurring between late September and early October (Gordon, 1975; Maxwell, 1986; CGNCDIA, 2018).
Winter weather typically arrives by October. October is one of the stormiest months of the year, with the strongest, coldest winds and greatest snowfall. During the depth of winter, temperatures can reach as low as $-40^{\circ} \mathrm{C}$ and arctic northwesterlies sweep tundra landscapes at speeds over $20 \mathrm{~km} / \mathrm{h}$, causing some of the coldest conditions in the country (Thompson, 1968; CGNCDIA, 2018). The southern forest, in contrast, is roughly $10^{\circ} \mathrm{C}$ warmer during winter, with wind speeds dropping to as low as $8 \mathrm{~km} / \mathrm{h}$. These conditions make for less severe blizzards and more hospitable living conditions, which reasonably influenced people's decisions to avoid overwintering on the northern tundra (Gordon, 1996).

Ikirahak is located in the west coast Hudson Bay lowland, which is characterized by countless lakes, rivers, streams, bogs, gullies, and thermokarst ponds (Fig. 2d) (Lee, 1968; Robinson, 1968). Many of these waterways were likely warm season travel routes connecting tundra and forest territories. They could also have been crosscut on foot or by sled after late September to early October 


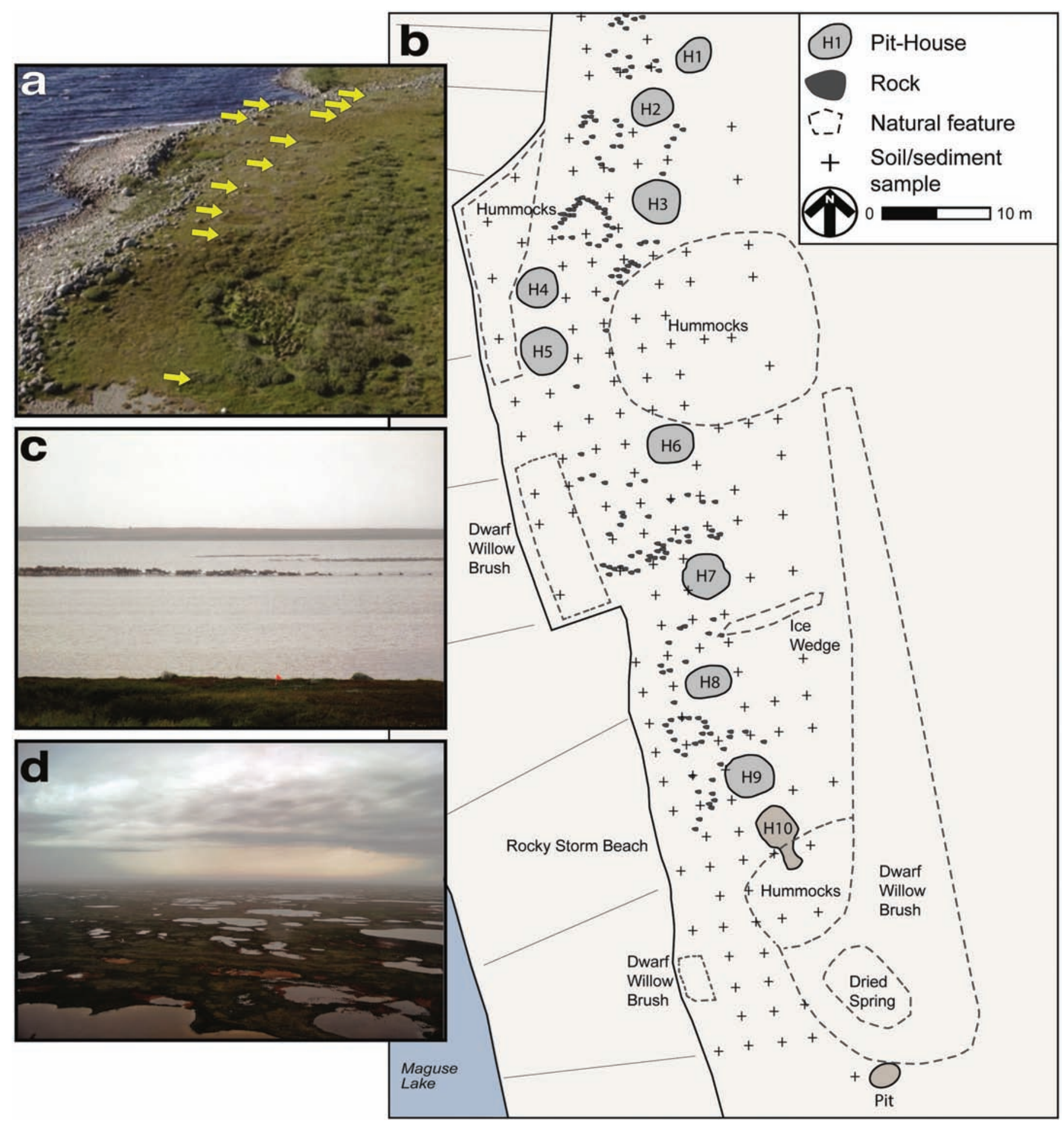

FIG. 2. The Ikirahak study site. a) Oblique aerial photograph of the site showing the pit-house depressions. b) Site plan showing the locations of pit-houses, natural features, and sediment core samples. c) A late summer caribou water crossing at Ikirahak Island. d) Oblique aerial photograph of the landscape in the Maguse Lake area.

freeze-up (Hanks, 1983; Gordon, 1996; Friesen, 2004). The area is also characterized by intricate esker systems that served as travel routes for caribou and people over thousands of years. Ikirahak Island itself is an esker (Aylsworth and Shilts, 1989; Gordon, 1996; McMartin and Henderson, 2004).
It is also possible that the locations of summer and winter territories were influenced by the position of the treeline. The treeline ecotone is a transitional band separating the tundra and boreal forest ecosystems (Gordon, 1996). The north-south width of the ecotone varies greatly, with maxima reaching $200 \mathrm{~km}$ in central Canada (Elliott-Fisk, 1983). Radiocarbon dating of buried stumps, cones, bark, 


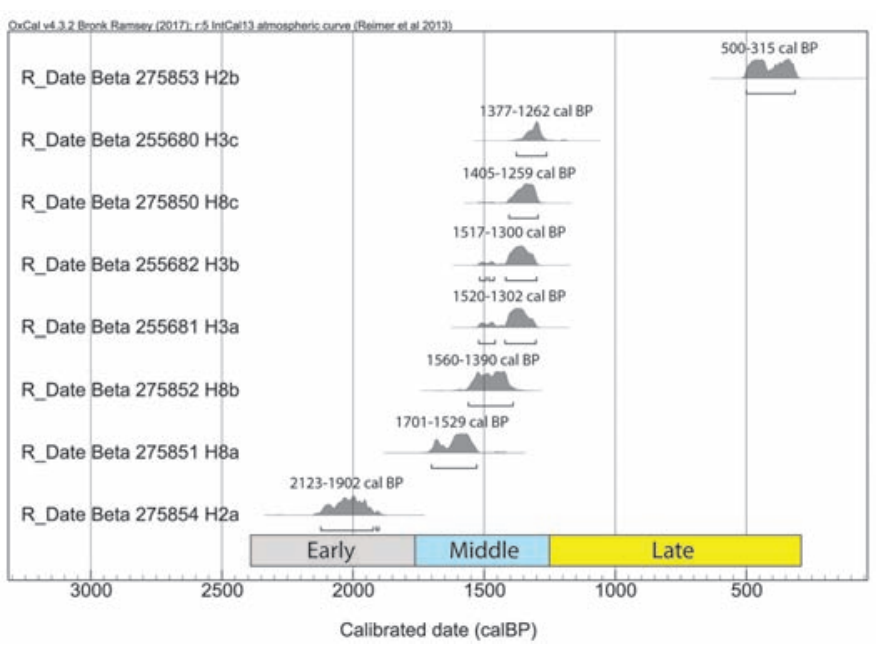

FIG. 3. Calibrated radiocarbon dates obtained from caribou bone collagen. Dates from Houses 2, 3, and 8 are plotted. There is a $95.4 \%$ probability that the recorded dates fall within the indicated ranges. Dates confirm occupations during the Early, Middle, and Late Taltheilei periods. Calibration and plotting was done using OxCAL Online.

and needles, pollen studies, and the formation of palaeosols indicate several treeline shifts since deglaciation. During the Holocene Climatic Optimum ( 9000 to $5000 \mathrm{BP})$ the treeline advanced to its furthest recorded northern position, upward of $300 \mathrm{~km}$ north of its current location (Gordon, 1996; Nichols, 1976; Sorenson et al., 1971). A retreat occurred between 4000 and 2800 BP (prior to Taltheilei). No northward shift reaching more than $160 \mathrm{~km}$ beyond the current position has been documented in southern Nunavut over the last 2000 to 3000 years (Nichols, 1967, 1972, 1976; Sorenson et al., 1971). An additional retreat associated with the Little Ice Age (Late Taltheilei) is suspected (ElliottFisk, 1983). Based on these studies, the Maguse Lake area was a tundra environment throughout all Taltheilei periods; however, it was at times closer to the treeline ecotone. Exactly when and how close is unclear.

\section{Typical Site Characteristics}

Across all Taltheilei periods, tundra site types are categorized as lithic scatters, stone markers, or ephemeral camps with low artifact densities. These sites are small and dispersed, reflecting small group sizes and high residential mobility (Gordon, 1996; Schwimmer et al., 1998; Friesen, 2004). Conversely, treeline and forest sites are larger, suggesting bigger communities and lower mobility. Large sites at the treeline are located near caribou water crossings and are thought to represent late summer camps used for large-scale caribou hunting and processing. Stone tent rings are the only dwelling features reported across all settings (Gordon, 1996).

Gordon (1996) presents an excellent overview of Taltheilei lithic and faunal assemblages recovered from the Beverly caribou range. Finds are categorized broadly into treeline to tundra and forest groups across each period. Total lithic counts and specific assemblage characteristics for individual sites are not detailed in the published literature. Assemblages did however exhibit several differences that were consistent across all periods. Points, scrapers, knives, chithos (hide abraders), cores, and flakes from forest sites were smaller than those from the tundra. This is interpreted as the result of sustained use and sharpening, as well as the inaccessibility of raw materials and increased sedentism. Scrapers and hide abraders, both of which are important hide processing tools, were typically more abundant at forest sites. They were smaller and more worn than their tundra counterparts, suggesting greater use.

Faunal evidence is limited. Aspects of caribou bone assemblages are reported in the published literature, though we suspect other species are represented as well. Forest sites such as those at Whitefish Lake typically yielded assemblages of less than 700 specimens, which included cranial bones, jaw fragments, teeth, axial elements including scapulae, vertebrae, ribs, and pelvic bones, as well as appendicular elements such as astragali, calcanea, humeri, fibulae, tibiae, ulnae, metacarpals, metatarsals, metapodials, and phalanges. These assemblages suggest the presence of complete animals and heavy processing at longer-term winter camps. A treeline, tundra interface site at Grant Lake (KkLn-4) yielded close to 600 bone fragments, while another at Wardens Grove (KjNb-7) produced an assemblage with over 1000 specimens. Appendicular elements are most commonly represented in treeline assemblages.

\section{ARCHAEOLOGICAL DISCOVERIES AT IKIRAHAK}

The site is located on the southern shore of Ikirahak Island and covers an area of $2090 \mathrm{~m}^{2}$ (Fig. 2a, b). Ten pithouses are arranged in roughly linear fashion parallel to the shoreline. Excavations were carried out on Houses 2, 3, 6 , and 8 using a $1 \mathrm{~m}$ square horizontal grid and arbitrary $10 \mathrm{~cm}$ vertical levels (Fig. 2b). Baulks $10 \mathrm{~cm}$ wide were left intact through the dwelling centers in order to record internal stratigraphy. Accelerator mass spectrometry radiocarbon dates obtained from caribou bone collagen confirmed occupations during the Early, Middle, and Late Taltheilei periods (Fig. 3). Materials from House 2 dated to the Early and Late periods, while materials from Houses 3 and 8 indicated repeated occupations during the Middle period. Samples from House 6 produced modern dates, suggesting disturbance by a somewhat recent occupation.

\section{Dwelling Architecture}

Dwellings were constructed by digging roughly $50 \mathrm{~cm}$ to $70 \mathrm{~cm}$ deep, $3.5 \mathrm{~m}$ to $4 \mathrm{~m}$ diameter pits into relict beach and esker sediments, then banking these sediments around the edges to create low wall berms (Fig. 4) (Hodgetts et al., 2011). Several large boulders were found inside Houses 2 and 8 and at the outer berm perimeter of House 6 . These were reasonably used to secure dwelling superstructures. 

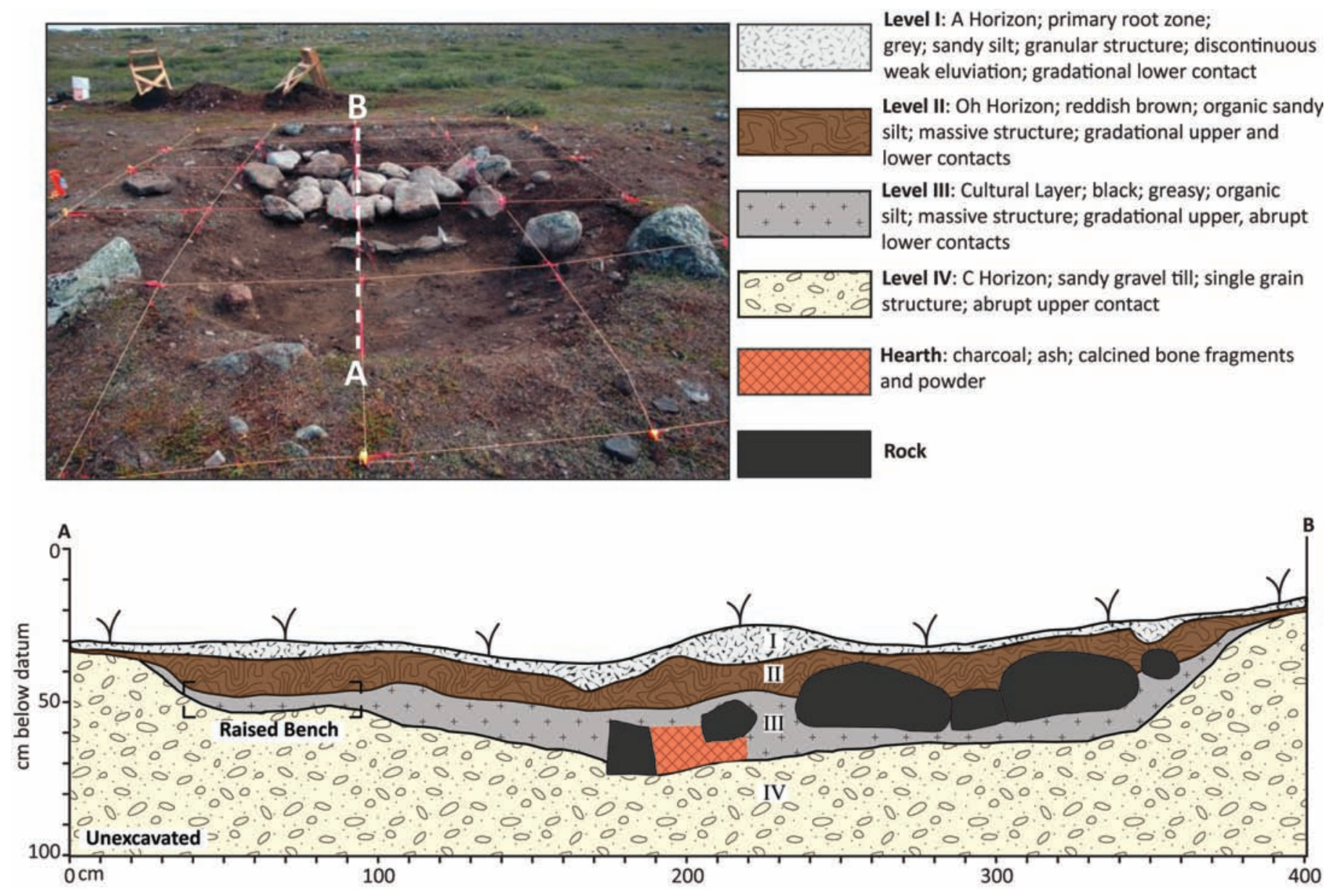

FIG. 4. Completed excavation of House 8. Note the cluster of large stones in the dwelling (photograph) and the raised bench area at the perimeter of the pit (profile drawing).

The boulders inside Houses 2 and 8 rest atop the cultural layers, which indicates they were pushed into the dwelling pits after terminal occupations (Fig. 4). House 6, as mentioned, was likely disturbed by more recent activities. Excavations uncovered a flagstone-paved area close to the surface. This appears to be a pre-modern feature built above the older dwelling components, which is supported by the recent radiocarbon dates obtained from recovered bone.

All four of the excavated dwellings had terracing along sections of their interior berm perimeters, which were likely constructed to serve as raised benches or platforms (Fig. 4). Clearly defined hearth features were discovered in the centers, which were the lowest elevation points in the houses. The hearth discovered in House 2 contained little burned material yet was marked by a circular concentration of stones. House 3's hearth was defined by cobbles, charcoal, and bone, while the House 8 hearth consisted of an abundance of charcoal and bone loosely outlined with stones. House 6 had a central oval-shaped alignment of stones. A concentration of charcoal and bone was found next to this stone feature.

A small pit at the southern periphery of the site appears too small to have served as a house (Fig. 2b). Sediment cores from the center of this feature did however contain charcoal and burned bone like the hearth features described above. The pit appears have been a house that became partially obscured by berm sediment mass-wasting.

\section{The Lithic Assemblage}

The lithic assemblage is the only one of its kind recovered from Taltheilei pit-house contexts. Assemblage details are presented in Figures 5 and 6 and Tables 1 and 2. A total of 9929 lithic artifacts were recovered. Three-point provenience was recorded for identifiable tools. The length, width, and thickness of all specimens were measured using digital calipers. Formal tool types such as points, scrapers, and bifaces were identified through comparisons with Taltheilei archetypes (Gordon, 1976, 1996). Expedient tools were defined as pieces of lithic material that were marginally modified or unmodified, used to complete a task, then discarded (Kooyman, 2000). Marginally modified tools include retouched flakes or retouched flake fragments. Retouched flakes retained their striking platforms but were further modified by removing a series of flakes from one or more lateral edges. 

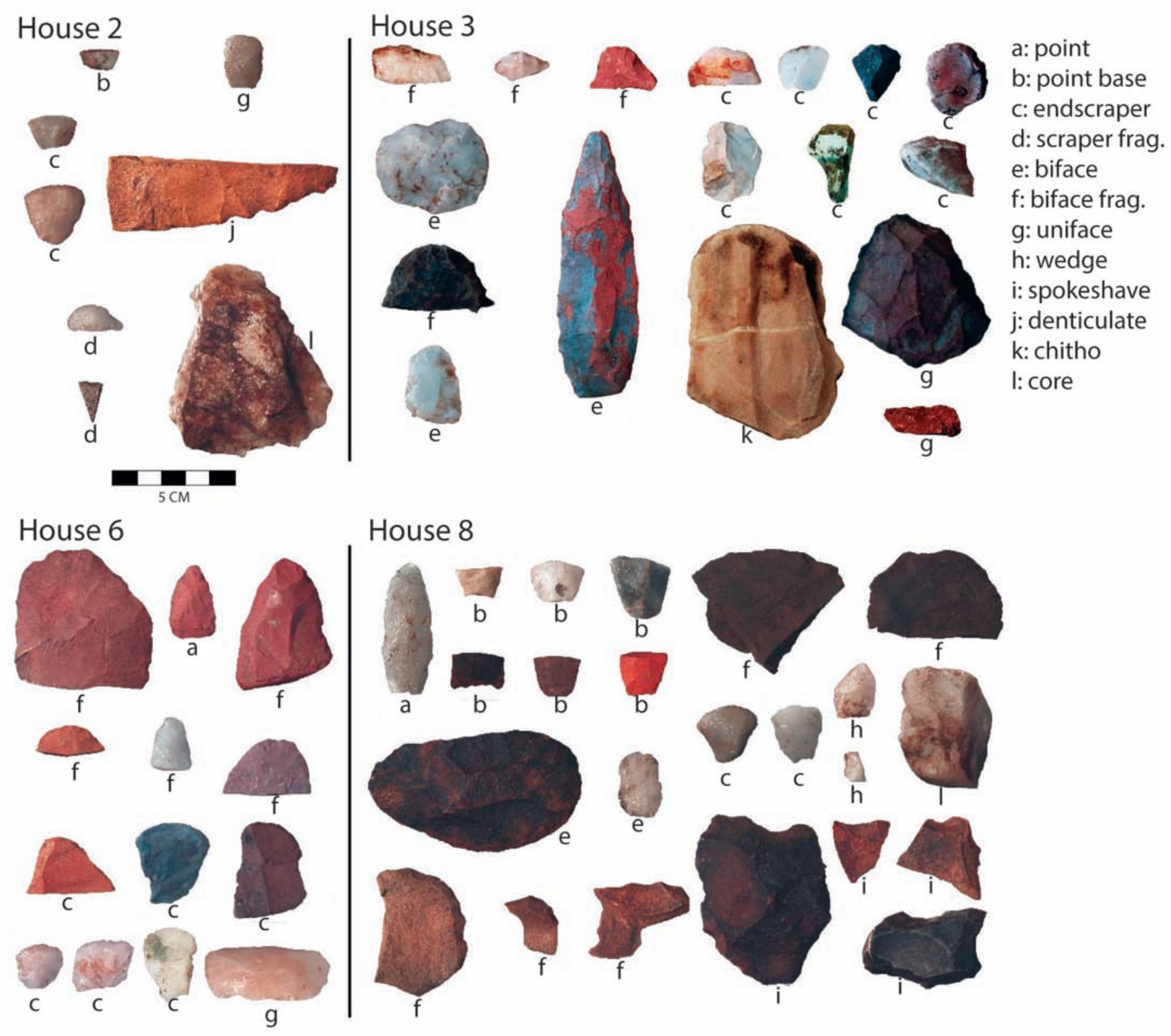

House 8
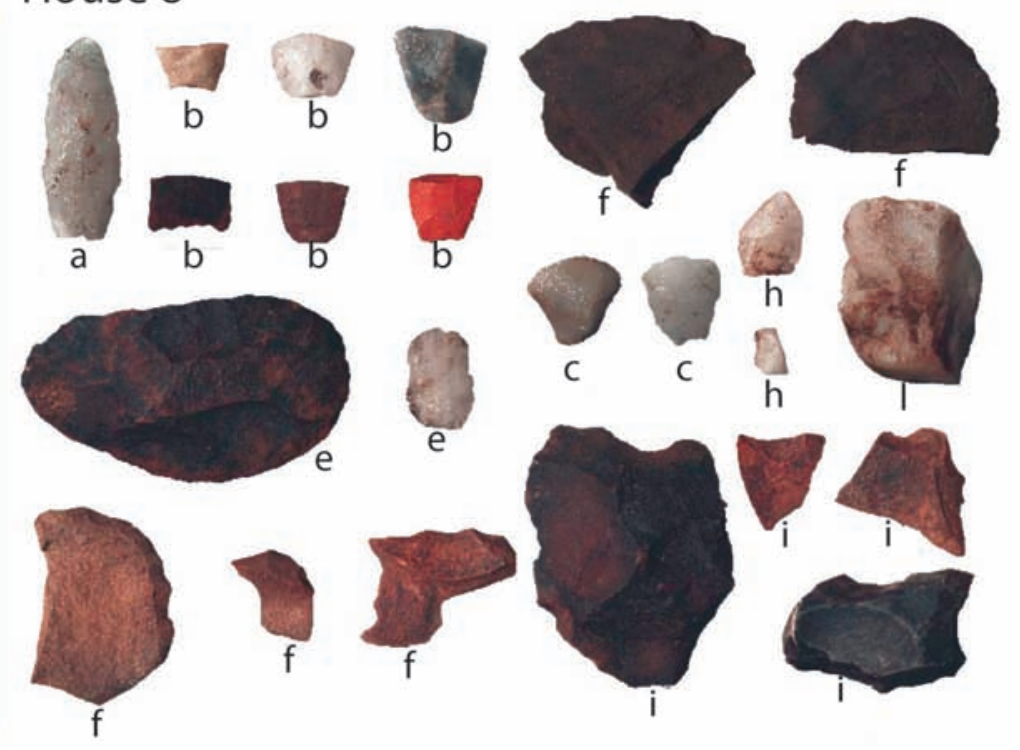

FIG. 5. Formal lithic tools recovered from Houses 2, 3, 6, and 8. The complete projectile point recovered from House 8 is diagnostic of Middle Taltheilei (a).

Debitage was counted by $1 \mathrm{~m} \times 1 \mathrm{~m}$ unit and classified into five types: (1) cores: pieces of lithic material with evidence of flake removal, but no indication of being tools; (2) platform-bearing flakes: debitage retaining all or some of their original striking platforms; (3) flake fragments: debitage with clearly discernable dorsal and ventral surfaces, but no clear striking platforms; (4) shatter: debitage with no discernable dorsal or ventral surfaces or any clear striking platforms; and (5) flake tools: pieces of lithic materials that have had their edges and dorsal or ventral surfaces further modified beyond detachment from a core, or unmodified lithic materials that show evidence of use wear on the edges.

Flakes were further categorized into reduction stages using the approach detailed by Kooyman (2000). Dorsal scars with widths greater than $5 \mathrm{~mm}$ were counted. Platform scars were only counted if they were large enough to cross the width of the striking platform. Flakes with zero to one dorsal and platform scars were considered early stage. Flakes with two dorsal and platform scars were considered middle stage, while flakes with three or more scars were considered late stage. If platform use wear was identified, the specimen was categorized as a late stage resharpening flake, even when it contradicted dorsal and platform scar counts. If a platform did not display evidence of use wear, its outline shape and the presence of acute exterior platform angles were used to determine the flake type. The amount of dorsal cortex present was also considered, as this is often indicative of earlier reduction stages. Dorsal cortex areas were estimated as follows: $0 \%, 1 \%-25 \%, 26 \%-50 \%$, $51 \%-75 \%, 76 \%-99 \%$, and $100 \%$. 
TABLE 1. Lithic tool types found in each pit-house. Expedient tools were the most abundant tool type, followed by bifaces, then scrapers.

\begin{tabular}{|c|c|c|c|c|c|}
\hline & $\mathrm{H} 2$ & H3 & H6 & $\mathrm{H} 8$ & Totals \\
\hline \multicolumn{6}{|l|}{ Formal tools: } \\
\hline Biface & - & 1 & 2 & 2 & 5 \\
\hline Biface fragment & - & 7 & 4 & 8 & 19 \\
\hline Biface fragment (ground) & - & - & 1 & - & 1 \\
\hline Bifacial symmetrical knife & - & 1 & - & - & 1 \\
\hline Chitho (hide abrader) & - & 1 & - & 1 & 2 \\
\hline Endscraper & 2 & 5 & 7 & 3 & 17 \\
\hline Sidescraper & - & 1 & 1 & - & 2 \\
\hline Scraper fragment & 1 & - & - & - & 1 \\
\hline Projectile point & - & - & - & 1 & 1 \\
\hline Projectile point base & 1 & - & - & 6 & 7 \\
\hline Projectile point preform & - & - & 1 & - & 1 \\
\hline Denticulate & 1 & - & - & - & 1 \\
\hline Graver & - & - & 1 & - & 1 \\
\hline Perforator & - & 1 & - & - & 1 \\
\hline Spokeshave & - & 2 & 2 & 4 & 8 \\
\hline Uniface & 1 & 3 & 3 & - & 7 \\
\hline Uniface fragment & - & 1 & 1 & - & 2 \\
\hline Wedge & 1 & 1 & 6 & 2 & 10 \\
\hline Total & 7 & 24 & 29 & 27 & 87 \\
\hline \multicolumn{6}{|l|}{ Expedient tools: } \\
\hline Retouched flake & 3 & 15 & 3 & 2 & 23 \\
\hline Retouched flake fragment & 3 & 6 & 5 & 4 & 18 \\
\hline Utilized flake & 1 & 5 & 15 & 3 & 24 \\
\hline Utilized flake fragment & - & 4 & 2 & 2 & 8 \\
\hline Total & 7 & 30 & 25 & 11 & 73 \\
\hline Overall total & 14 & 54 & 54 & 38 & 160 \\
\hline
\end{tabular}

Tools were made from a red silicified volcaniclastic stone and white quartzite, both of which are available on Ikirahak Island. No exotic materials were discovered. Eleven formal and two expedient tool types were identified (Fig. 5, Table 1). Overall, expedient tools were most abundant, comprising close to half of the identified tool assemblage. Of the 87 formal tools identified, bifaces and biface fragments were most common $(30 \%)$, followed closely by scrapers (23\%). Houses 3,6 , and 8 had similar tool quantities, whereas House 2 produced very few.

There was an emphasis on middle stage reduction $(20 \%$ of the entire assemblage; $64 \%$ of the identifiable debitage assemblage). Late stage finishing and resharpening flakes were the next most abundant debitage types. Houses 6 and 8 produced the greatest amounts of lithic debitage, and House 2 the least by a wide margin (Table 2). Based on the spatial distributions of lithic debitage, it appears that knapping activities were primarily conducted around the central hearths of the dwellings. For instance, large amounts of debitage and tools were associated with the House 6 hearth (Fig. 6a, b). Higher frequencies of lithic debitage smaller than $3 \mathrm{~cm}$ were also recovered from internal floor perimeters (Fig. 6a). The assemblage suggests that hunting gear was being made and maintained at the site.

\section{The Faunal Assemblage}

A total of 320 specimens were collected (Table $3 a, b$ ). The length, width, and thickness of all specimens were
TABLE 2. Lithic debitage organized by reduction stage. The majority of the identified debitage was classified to the middle stage of reduction.

\begin{tabular}{|c|c|c|c|c|c|}
\hline Reduction stage & $\mathrm{H} 2$ & H3 & H6 & $\mathrm{H} 8$ & Total \\
\hline \multicolumn{6}{|l|}{ Early stage reduction: } \\
\hline Bipolar & - & 8 & - & 1 & 9 \\
\hline Core rejuvenation & - & - & 1 & - & 1 \\
\hline Primary decortication & 1 & 4 & 2 & 8 & 15 \\
\hline Secondary decortication & - & 8 & 7 & 26 & 41 \\
\hline Secondary & 15 & 17 & - & 34 & 66 \\
\hline Undefined & - & 38 & 4 & 2 & 44 \\
\hline Total & 16 & 75 & 14 & 71 & 176 \\
\hline \multicolumn{6}{|l|}{ Middle stage reduction: } \\
\hline Shaping & 45 & 246 & 499 & 550 & 1340 \\
\hline Thinning & 77 & 165 & 457 & 229 & 928 \\
\hline Undefined & 17 & - & 255 & 70 & 342 \\
\hline Total & 139 & 411 & 1211 & 849 & 2610 \\
\hline \multicolumn{6}{|l|}{ Late stage reduction: } \\
\hline Biface reduction & 7 & 34 & 122 & 149 & 312 \\
\hline Finishing & 12 & 55 & 170 & 265 & 502 \\
\hline Resharpening & 2 & 41 & 104 & 323 & 470 \\
\hline Undefined & - & - & 15 & 15 & 30 \\
\hline Total & 21 & 130 & 411 & 752 & 1314 \\
\hline Overall total & 176 & 616 & 1636 & 1672 & 4100 \\
\hline
\end{tabular}

measured using digital calipers. Identifications were made using comparative collections of northern species and taphonomic modifications. Considering that only roughly $30 \%-40 \%$ of the identifiable features at the site have been investigated, we expect that further excavations of the remaining features will increase the assemblage to a size comparable to, or greater than, other reported tundra assemblages ( 600-1000 NISP) (Gordon, 1996). As described above, faunal assemblages from Taltheilei sites are rare, with fewer than a dozen other assemblages published with any level of detail (Gordon, 1996). Our assemblage, despite its size, therefore makes a very important contribution to this database of finds.

Systemic and post-depositional site formation and taphonomic factors must be addressed nonetheless. Bone refuse may have been discarded at primary butchering locations away from the camp. Refuse may have also been tossed into the lake or to the lake edge, the latter of which would expose remains to winter ice rafting. There is strong evidence for bone burning. Over three quarters of the specimens from Houses 2 and 8 were partially burned or calcined (Table 3c). Bones were burned so intensely that they were reduced to powder and tiny fragments. A subsample of these fragments was investigated by Fourier transform infrared spectroscopy (FTIR, potassium bromide method). Their mineral component was highly crystalline, indicating burning at temperatures upward of $700^{\circ}-800^{\circ} \mathrm{C}$ (Butler and Dawson, 2013). The large amounts of powder and tiny fragments discovered were not included in the calcined bone counts.

Bone processing (i.e., marrow removal) likely played a role in reducing the number of identifiable elements, which is suggested by the high degree of fragmentation recorded 


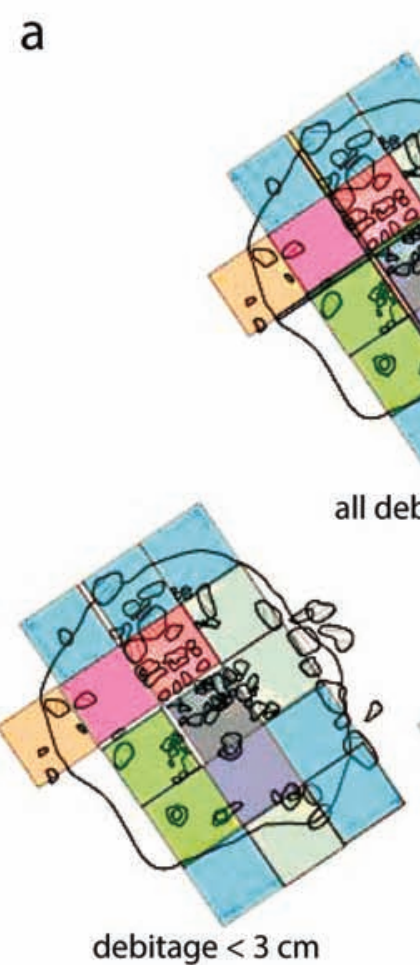

debitage $<3 \mathrm{~cm}$

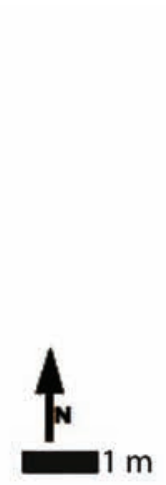

b

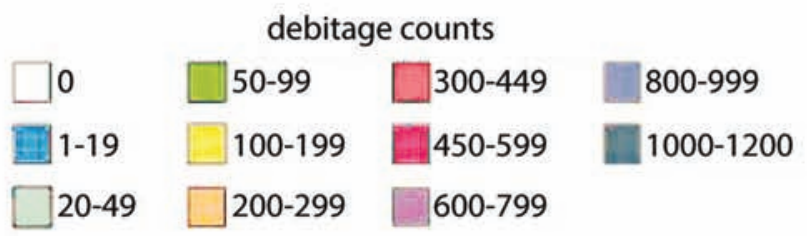

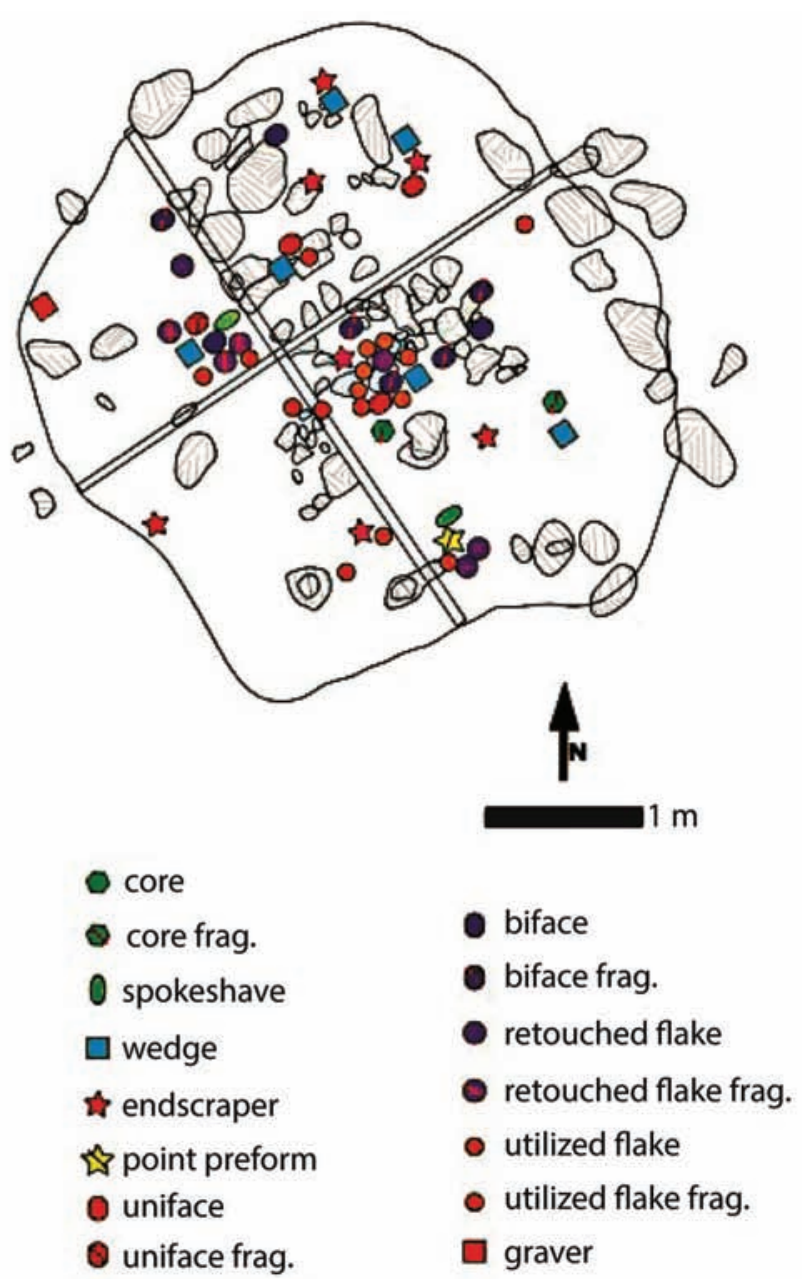

FIG. 6. Lithic debitage size classes (a) and tools (b) recovered from House 6. Note the larger frequencies of small debitage in the hearth context and along the southwest/west perimeter. Most of the tools were also found in the hearth context. Several of the tools from House 6 are depicted in Fig. 5 .

among non-calcined bones. Close to half of the specimens collected could not be identified taxonomically because of fragmentation. A more detailed analysis of materials from Houses 2 and 8 showed that close to $90 \%$ of the materials recovered from these locations ranged between 0.5 and $2.4 \mathrm{~cm}$ in their largest dimension (Table $3 \mathrm{~d}$ ).

Post-depositional decomposition of lower density bone elements could also cause an overrepresentation of denser specimens; yet, we have no reason to suspect that the bone assemblage has been compromised by the complete dissolution of lower density elements. One lumbar vertebra (a lower density element) was recovered, which indicates that lower density caribou elements should be preserved in this context. The cortical surfaces of most unburned specimens were smooth and largely intact, and the edges of most broken specimens were sharp and robust. Mineralogical analyses of bone samples also confirmed the good preservation state of the assemblage. Our FTIR analyses of unburned bone excavated from dwelling contexts identified mineral components that were not drastically altered. Their mineral components were similar to modern bone, indicating that bone mineral is chemically stable in this burial environment (see Butler and Dawson,
2013 and references therein). These findings suggest the caribou element distribution in assemblages has not been skewed toward higher density elements by aggressive dissolution.

Mammal and bird bones were identified (Table 3a). Specimens from caribou and the more general taxonomic classification artiodactyl were the most abundant identifiable bones, together comprising a quarter of the total assemblage and half of the classifiable bones. It is likely that all of the artiodactyl specimens collected are from caribou. Moose is the only other artiodactyl in the region, yet these animals are typically found in the southern boreal forest (Bowyer et al., 2003). Their bones are also notably larger and more robust than the specimens recovered from Ikirahak. Long bone fragments dominated the caribou (artiodactyl) assemblage (Table 3b). No elements indicative of high yield units were found (e.g., axial elements such as ribs) (Lyman, 1994). No cranial elements were found. As mentioned, a single axial element (lumbar vertebra) was recovered. Given the unlikelihood of assemblage skewing owing to diagenesis, the absence of lower density higher yield elements is not taphonomic, but behavioural. Higher yield units were processed and discarded elsewhere. 
TABLE 3. Characteristics of the faunal assemblage. a) Total number of individual specimens and the represented taxa from Houses 2, 3, 6, and 8. Caribou (artiodactyl) are most abundant. b) Caribou (artiodactyl) elements recovered from Houses 2, 3, 6 , and 8. Most elements come from the appendicular skeleton. c) Modifications identified on specimens from Houses 2 and 8 . d) Degree of bone fragmentation recorded in Houses 2 and 8.

\begin{tabular}{lcc}
\hline a) Taxa represented in Houses 2, 3, 6,8 & & \\
Taxa & NISP & $\%$ \\
\hline Artiodactyls & 59 & 18 \\
Caribou & 23 & 7 \\
Large terrestrial mammal & 35 & 11 \\
Terrestrial mammal & 40 & 13 \\
Mammal & 4 & 1.5 \\
Mammal or bird & 1 & 0.4 \\
Large bird & 2 & 0.7 \\
Grouse/Ptarmigan & 1 & 0.4 \\
Indeterminate & 155 & 48 \\
Total & 320 & 100
\end{tabular}

b) Caribou (Artiodactyl) elements in Houses 2, 3, 6, 8

\begin{tabular}{lcc} 
Element & NISP & $\%$ \\
\hline Long bone & 58 & 70 \\
Tibia & 7 & 8 \\
Teeth & 5 & 6 \\
Femur & 2 & 2.5 \\
Humerus & 2 & 2.5 \\
Metapodial & 2 & 2.5 \\
Metacarpal & 2 & 2.5 \\
Astragalus & 2 & 2.5 \\
Phalanx & 1 & 1 \\
Lumbar & 1 & 1 \\
Total & 82 & 100
\end{tabular}

c) Bone modifications in Houses 2 and 8

\begin{tabular}{lrc} 
Modification & NISP & $\%$ \\
\hline Burned & 15 & 7.8 \\
Calcined & 148 & 77.2 \\
Spiral fracture & 1 & 0.5 \\
Lengthwise split & 1 & 0.5 \\
Root etching & 1 & 0.5 \\
No modification & 26 & 13.5 \\
Total & 192 & 100
\end{tabular}

d) Bone fragmentation in Houses 2 and 8

\begin{tabular}{lcc} 
Fragment size $(\mathrm{cm})$ & NISP & $\%$ \\
\hline $0.5-1.4$ & 50 & 48 \\
$1.5-2.4$ & 45 & 41.6 \\
$2.5-3.4$ & 10 & 5.2 \\
$3.5-4.4$ & 3 & 1.6 \\
$4.5-5.4$ & 3 & 1.6 \\
$6.5-7.4$ & 1 & 0.5 \\
$7.5-9.9$ & 1 & 0.5 \\
$>10$ & 2 & 1 \\
Total & 115 & 100 \\
\hline \hline
\end{tabular}

\section{Sediment Characteristics}

We collected 173 sediment samples along a $3 \mathrm{~m}$ sitewide lattice grid using a small-bore Oakfield corer (Fig. 2b). Charcoal and lithic debitage were identified in several cores (Fig. 7). Sediments were also collected from dwelling floors and hearth features during excavations. The multi-element compositions of the sediments were characterized using laboratory-based wavelength-dispersive x-ray fluorescence
(WD-XRF, powdering, homogenization, and phenolic resin mounting) and inductively coupled plasma mass spectroscopy (ICP-MS, strong acid digests) (see Butler and Dawson, 2018 for details).

Enriched concentrations of several elements commonly tied to human habitation were identified (Griffith, 1980, 1981; Moore and Denton, 1988; Middleton and Price, 1996; Knudson et al., 2004; Wells et al., 2004; Cook et al., 2006; Linderholm, 2007; Wilson et al., 2008; Middleton et al., 2010; Misarti et al., 2011; Milek and Roberts, 2013; Rondelli et al., 2014). Manganese, for example, had on-site concentrations upward of 45 times higher than off-site control sediments. Phosphorus, calcium, and copper had enrichments as high as 4, 6, and 12 times greater than offsite control sediments respectively. Principal component analysis and inverse distance weighted interpolation highlighted interesting enrichment patterns across the site (see Butler et al., 2018 for details). Calcium, magnesium, copper, and phosphorus, for instance, had their highest enrichments in hearth contexts and in open-air locations close to the dwellings (Fig. 7). Strong potassium, iron, magnesium, and strontium anomalies were also detected in several open spaces (Butler et al., 2018).

Sediment mineralogy was explored using FTIR (potassium bromide method; see Butler and Dawson, 2013 for details). White granular powders and small chalky fragments from hearth features were defined as highly calcined bones and wood ash calcite.

\section{QUESTIONS OF TIMING}

As outlined above, tundra sites are small and dispersed, reflecting small group sizes and high residential mobility during the summer months (Gordon, 1996). Ikirahak was north of the closed forest the entire time that Taltheilei people were living in the Barrenlands. It was located hundreds of kilometers away from suspected forest wintering territories (Fig. 1, d-h). The site does not appear to represent an ephemeral summer camp. The presence of pit-house dwellings, the strong anthropogenic influence on sediment chemistry, and aspects of the lithic and faunal assemblages raise questions concerning residential mobility, seasonality, and site functions. On the basis of this evidence, we hypothesize that Ikirahak represents a longerterm, colder season camp. Specifically, by "longer" we mean longer relative to the highly ephemeral camps typical of the tundra, and by "cold season" we mean late fall.

\section{Residential Mobility}

Dwelling architecture, cleaning activities, and tool use at Ikirahak offer insights into the question of residential mobility (see, for example, Kelly, 1983, 1992, 1995; Carr, 1984; Oswald, 1984; O’Connell, 1987; Kelly and Todd, 1988; Binford, 1990; Kent, 1991; Panja, 2003; Kelly et al., 2005; Oetelaar and Meyer, 2006; and Grove, 2009 


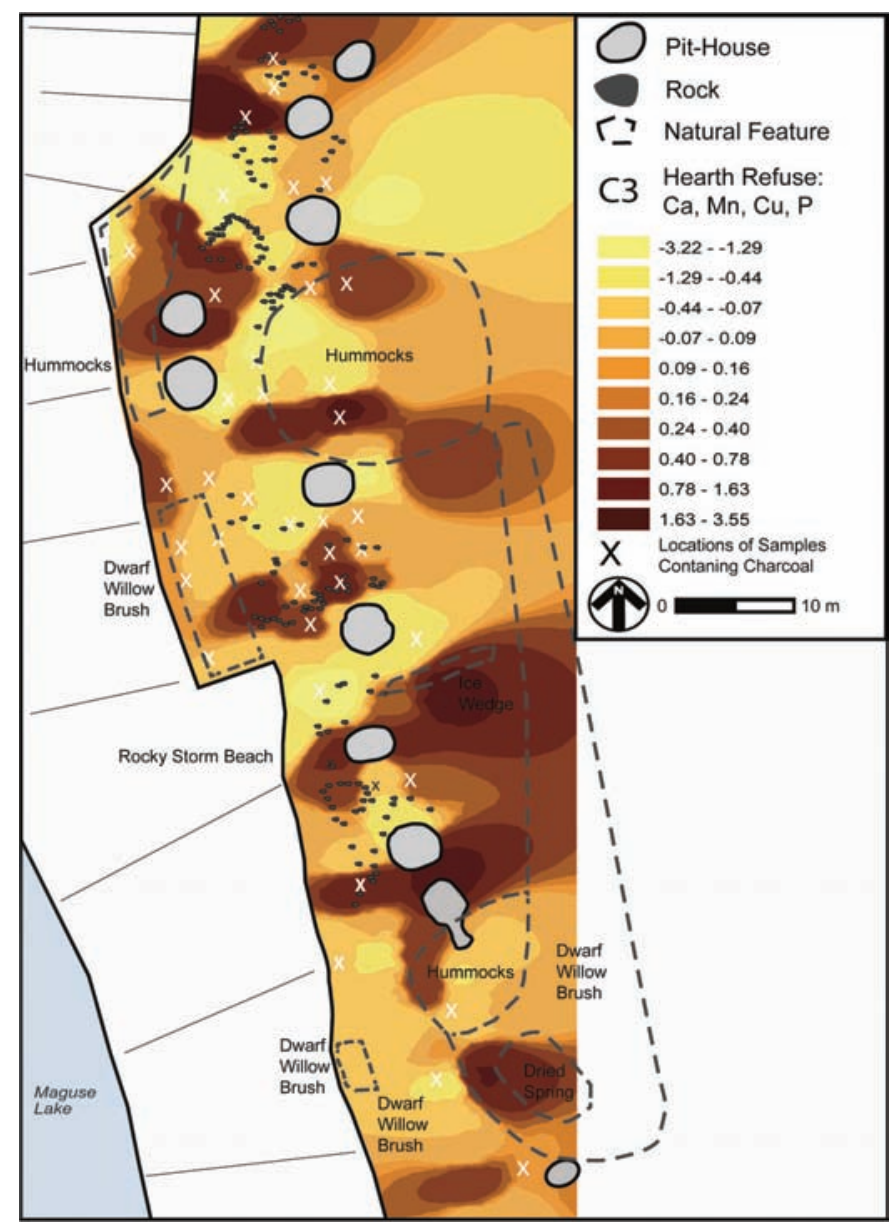

FIG. 7. Spatial structuring in element enrichments. This map depicts the inverse distance weighted interpolation of a principal component analysis correlating the elements calcium, copper, manganese, and phosphorus. The isopleths represent principal component scores for the correlated elements. Darker areas have higher element concentrations. Core sample locations containing charcoal are also marked.

for detailed discussions of indicators for hunter-gatherer residential mobility). An investment of time and labour into building and maintaining pit-houses is consistent with lower residential mobility (McGuire and Schiffer, 1983; Gilman, 1987; Binford, 1990; Kelly, 1992). We suspect that digging pit-houses at Ikirahak was more labour intensive than pitching aboveground tent structures. Deposits at Ikirahak are mainly coarse tills, which we believe were somewhat time consuming to dig with the stone, bone, and wooden tools available to Taltheilei people. The only direct comparison with published tundra dwellings we can draw comes from a cluster of four tent ring sites around the south end of Skinny Lake (Fig. 1: c). The use of aboveground tents at these sites suggests lower construction investments and shorter occupations (Friesen, 2004). Conversely, we propose that the Ikirahak pit-houses represent a need to invest in building dwellings that would be used for longer occupations.

Dwelling maintenance and refuse disposal practices are also indicators of residential mobility (O'Connell, 1987; Kent, 1991; Oetelaar, 1993; Bamforth et al., 2005).
Sites occupied for longer periods are expected to be more formally maintained. Hearth maintenance at Ikirahak was indicated by our multi-element sediment characterization studies. Owing to large inputs of ash, charcoal, bone, and fats, hearth sediments had highly enriched concentrations of calcium, manganese, copper, and phosphorus. Concurrently, the open-air spatial structuring of charcoal and calcium, manganese, copper, and phosphorus enrichments suggested that hearth refuse was dumped in designated spaces adjacent to the dwellings and subsequently dispersed across the camp (Fig. 7) (Butler et al., 2018). This type of refuse disposal behaviour suggests lower residential mobility (Carr, 1984; Oswald, 1984; O'Connell, 1987).

The use of large amounts of fuel over short periods of time may leave similar signatures. We propose, however, that this scenario only carries weight in situations where fires were consistently maintained at their maximum capacities. This practice would have been an unsustainable use of limited fuels at Ikirahak. There is little wood fuel available on the island (Fig 2a). It is more reasonable that fuels were used carefully, and fires were kept relatively small. We give more weight to the scenario that the imprinted signatures were formed gradually, through the cleaning and dumping of fuel refuse produced gradually during both longer-term and repeated occupations, rather than rapidly during short-term one-off visits.

When these hearths were cleaned and their contents dumped outside, the lithic wastes temporarily disposed of in hearths were dumped as well. Support for this scenario comes from the lithic refuse found scattered across the surface and in site-wide sediment cores. Dwelling lithic counts are suspected to have been reduced by this process. It is also important to recognize that the total lithic assemblage we recorded could have been produced over short periods of time. The low amount of debitage recovered from House 2, for instance, could indicate shortterm occupation, or it may represent cleaning.

Greater frequencies of lithic debitage smaller than $3 \mathrm{~cm}$ were documented along the internal berm perimeters of the houses (Fig. 6a). The spatial patterning suggests the cleaning tasks expected in houses occupied for longer periods of time (Janes, 1989; Oetelaar, 2000). These distribution patterns may also relate to the redistribution of debris via scuffing (Stevenson, 1985, 1991). Moreover, cleaning episodes could indicate the preparation of the camp in anticipation of future reoccupation, or preparation immediately prior to reoccupation (Kent, 1991).

The stone tool assemblage provided somewhat ambiguous evidence for residential mobility. The exclusive use of locally available raw materials suggests lower residential mobility (Pickering, 2012). The diverse tool kit represented at the site implies that people undertook a broad array of activities, which is also widely used as an indicator of lower residential mobility (Yellen, 1977; Binford, 1980; Shott, 1986; Hitchock, 1987; Cowan, 1999). Tool representation was similar at the Middle Taltheilei 
Migod site, which is interpreted as an ephemeral summer camp (Gordon, 1976). Conversely, all houses at Ikirahak contained higher ratios of expedient to formal tools and evidence of bifacial reduction when compared to Migod. No expedient tools were reported from Migod (Gordon, 1976). This suggests lower residential mobility at Ikirahak.

Houses 6 and 8 had higher frequencies of resharpening flakes, which compares favourably with shorter-term pithouse occupations in the Lillooet region of British Columbia (Magne, 1985). That said however, such analogues may not be appropriate for interpreting Taltheilei assemblages. Tundra sites were highly ephemeral, leaving behind few remains. A longer-term occupation of a tundra site among the Taltheilei may have been a few weeks and likely less than two months. While this is longer than anticipated for occupation lengths at ephemeral camps, the assemblages are expected to appear small when compared to those produced by groups living in the same location over several months. From our perspective, within the Taltheilei culture, and among tundra sites in particular, the pit-house features, dates, material assemblages, and strong element anomalies at Ikirahak are not suggestive of a handful of ephemeral occupations.

\section{Seasonality}

The use of pit-houses, the isolation of hearths and tool making and maintenance to dwelling interiors, and indicators for fuel selection and management at Ikirahak support our hypothesis that the site was occupied during the colder part of the year (see, for instance, Monks, 1981; Hanks, 1983; Oswald, 1984; Hitchcock, 1987; Rocek, 1988; Bettinger, 1989; Simms, 1989; Oetelaar, 1993; Panja, 2003; and Goldberg et al., 2012 for discussions on seasonality indicators). We propose that investments into constructing pit-houses reflect a need for more thermally efficient dwellings. Pit-houses provide several thermoregulative advantages and are thus a widespread adaptation to cold weather (Gilman, 1987; Lee and Reinhardt, 2003). Studies of thermal efficiency show that semi-subterranean structures retain more heat than surface dwellings because the surrounding soil and other sediment maintain a more constant temperature (USCUOM, 1979). It is also wellknown that internal terracing causes dense cold air to settle at low points, while lighter warm air rises into higher areas (Park, 1997; Le Mouël and Le Mouël, 2001). This type of internal architecture was documented in all of the houses excavated at Ikirahak. Moreover, the most reasonable function of the large boulders associated with Houses 2, 6, and 8 was to secure superstructures against strong October winds (Fig. 4). October is one of the stormiest and windiest months of the year (Maxwell, 1986). It is also unlikely that these houses were dug and occupied during the spring, as the ground was still frozen and winter runoff could flood the dwellings. Occupations likely began during the late summer and extended into the late fall.
Comparatively, Hudson Bay Company photographs of late 19th to early 20th century Dene (Chipewyan) warm season camps at the treeline and at Great Slave Lake document the use of conical hide tents that have no signs of bermed foundations or the use of large boulders securing superstructures (see photographs in Gordon, 1996:30, 49). There is no evidence suggesting these people built pit-houses. In Alaska, people of the ProtoAthapaskan tradition (likely the ancestors of the Taltheilei) used both aboveground tent structures and pit-houses. This architectural variability is suspected to represent adaptations to the challenges presented by summer and winter conditions respectively (Clark, 2001). Similarly, the historic period Cree people of the eastern Subarctic built pit-house structures between September and October for exclusive use during the winter. Aboveground tents were used during the warmer months (Hanks, 1983). Expanding the comparative scope further, Lee and Reinhardt (2003), in their extensive review of "Eskimo" dwellings across the North American Arctic, describe the use of several varieties of semi-subterranean dwellings during the winter months in the central Arctic. All examples of summer dwellings involved the construction of aboveground tent structures.

Hearth types and fuel selection have also proven useful in seasonality studies (Hanks, 1983; Pokotylo and Hanks, 1989; Stiner et al., 1995; Schiegl, et al., 2003; Goldberg et al., 2012). Our evidence for pyrotechnology suggests cold season occupations. Both the faunal and FTIR analyses confirmed the presence of significant amounts of calcined bone fragments and powdery bone ash in hearth contexts. This evidence is consistent with the pattern expected from several heating episodes, with bones being broken down into smaller fragments through each successive firing (Costamango et al., 2005). At Ikirahak, this suggests intensive hearth use during the final stages of occupation. The length of time it would take to create such a deposit is unclear; however, based on the amounts of bone ash and fragments recorded, it appears that large amounts of bone were burned.

Higher percentages of unclassifiable calcined bone fragments relative to those of partially burned or carbonized, yet still classifiable bone is consistent with the use of bone as fuel (Costamango et al., 2005; ThéryParisot and Costamagno, 2005). Ikirahak hearths contained many unclassifiable calcined bone fragments burned at temperatures of approximately $700^{\circ} \mathrm{C}-800^{\circ} \mathrm{C}$ (Butler and Dawson, 2013). A reliable supply of wood is lacking at Ikirahak; yet during the fall caribou-hunting season, caribou bone would have been abundant, and would therefore have provided a viable alternative fuel source. Bone fuel would be particularly important during September and October, as snow and ice probably already covered the small lowlying wood source available at Ikirahak (Fig. 2a). Adding fresh bone to a hearth also improves fire health, increasing its duration and the production of radiative and convective heat (Théry-Parisot, 2002; Théry-Parisot and Costamagno, 2005). 
That being said, however, bone could have been used as fuel at any time of the year. Overall, there is little wood fuel available on Ikirahak Island, which means bone was reasonably used as a fuel supplement, specifically as a way to conserve limited wood. Another explanation for the preponderance of calcined bone fragments and bone ash in the Ikirahak hearths is waste management. People could have burned bone refuse to keep their dwellings and open-air workspaces free of debris. If this were the case, our evidence for bone burning would provide additional support for the argument that the site was occupied for longer periods of time (Oswald, 1984; Hitchcock, 1987; Oetelaar, 1993). Coupled with the pit-house architecture, however, we give more weight to the possibility that bone was used to supplement other fuel sources. Bone burning also implies that people were aiming to conserve fuel resources, which in turn suggests longer stays that would demand greater fuel supplies.

Animal bone marrow provided a vital source of several vitamins and nutrients, particularly vitamin $\mathrm{C}$. For this reason, people are thought to have avoided using raw bone and fat as fuel sources in marginal northern environments, instead using these resources for sustenance. Experimental and archaeological studies show that several different factors, including fat content, size, and porosity influence how well bone burns (Stiner et al., 1995; Théry-Parisot, 2002; Théry-Parisot and Costamagno, 2005; Mentzer, 2009, 2014; Aldeias, 2017). Marrow extraction or fat rendering via boiling are expected to reduce the value of processed bone as a fuel source (Costamango et al., 1998).

More comprehensive experimental work, however, demonstrates close correspondences in the intensity of combustion and the production of calcined fragments across complete long bones, both fresh and dry, as well as fractured long bones lacking marrow (Costamango et al., 2005). The removal of marrow may reduce bone flammability, yet the collagen component making up roughly $20 \%$ of the bone, as well as residual fats liberated from internal pore space upon heating, are still expected to make processed bone a somewhat viable fuel source. The state of the faunal assemblage at Ikirahak suggests that bone provided valuable food and fuel resources. Similarly, the use of ruminant bone as a fuel source was also identified at the 14000-year-old Swan Point site in Alaska (Kedrowski et al., 2009). These findings support the hypothesis that people in marginal areas of the North American Arctic relied on bone fuels to a wider extent than previously considered.

Hearth locations provide insights into seasonality (Bettinger, 1989; Goldberg et al., 2012). Hearths at Ikirahak were exclusively established inside dwellings. External hearths and smudge pits could be used for hide and meat smoking and mosquito control during warmer months, yet there are no sheltered fire pits installed anywhere across the site (Binford, 1967). It would have been an inefficient use of sparse fuel to maintain outdoor fires during colder seasons, as these fires offered no protection against wind and moisture and therefore required significantly more fuel to produce a sustainable amount of heat. The exclusive use of dwelling hearths supports the hypothesis that people aimed to optimize fuel use by only heating spaces better suited for heat retention, in turn suggesting colder season occupations.

The lithic assemblage suggests that hunting gear was being made and maintained at the site. Manufacturing and maintenance also appear to have been isolated to dwelling hearth spaces. During warmer seasons, we expect some lithic reduction to have occurred outdoors owing to easier debris clean up, the option to conduct tool making activities in spaces that did not require immediate clean up, and the advantage of excellent lighting conditions. We did not identify any open-air spatial patterns of lithic debris that would indicate the establishment of dedicated outdoor workshops. The majority of lithic finds were isolated to dwelling interiors, suggesting most tool manufacturing and maintenance were done inside. Knapping requires fine motor dexterity, which would be compromised when working in cold conditions for extended periods, either because of the challenge of working with exposed hands for long periods or the difficulty of working with gloves. The decision to undertake knapping activities in poorly lit dwellings was reasonably influenced by the warmth offered by hearths

\section{QUESTIONS CONCERNING LAND USE DECISIONS}

When considered together, the evidence recovered from Ikirahak does not accord with conventional understandings of Taltheilei tundra land use (Tables 4 and 5). Our findings suggest that Ikirahak was not a short-lived summer encampment. Ikirahak does, however, share characteristics with treeline sites from the Beverly Range (Gordon, 1996). The function of Beverly treeline sites as caribou hunting and processing base camps is suggested by their positioning near prominent caribou water crossings and an overrepresentation of appendicular caribou elements. People gathered at these places toward summer's end in order to intercept large caribou herds migrating into their forest wintering grounds (Gordon, 1996).

Ikirahak was also likely a key hunting and processing location. While the site is near caribou water crossings at the narrows of Maguse Lake, and its faunal assemblage does display an overrepresentation of appendicular elements and highly fragmented bone, it is distinctly characterized by the use and maintenance of pit-house dwellings (Fig. 2c, Table 3). We suspect that the treeline ecotone was at times closer to Maguse Lake, meaning Ikirahak may have occasionally been a treeline site type. Yet, as mentioned, Maguse Lake was a tundra environment throughout all Taltheilei periods. While the treeline ecotone did at times expand farther north, there is no evidence to suggest that Ikirahak was any closer to the true, closed boreal forest or suspected wintering grounds (Fig. 1: $d-$ g). 
TABLE 4. Summary of evidence and interpretations relating to seasonality and mobility. Seasonality and mobility are interpreted in terms relative to short-term summer tundra camps.

\begin{tabular}{lcc}
\hline \hline Characteristics & Seasonality & Mobility \\
\hline Dwelling architecture: $\sim 50-70$ cm deep pits with raised platforms & colder & lower \\
Dwelling maintenance: floor and hearth cleaning & - & lower \\
Lithic quantity: likely higher than ephemeral sites $(\mathrm{n}=9929)$ & - & lower \\
Lithic material selection: primarily local materials & - & lower \\
Lithic debitage representation: emphasis on mid $(64 \%)$ and late $(33 \%)$ stage & colder & lower \\
Tool making and maintenance: primarily within dwellings & -- & - \\
Lithic tool representation: emphasis on expedient tools $(45 \%)$ & - & lower \\
Fauna quantity: relatively low (n=320) & fall & higher \\
Species representation: caribou/artiodactyl $(50 \%$ of specimens identified) & - & lower \\
Bone modifications: abundance of fragmented/calcined bone & colder & lower \\
Fuel use: wood supplies supplemented with animal bone & colder & - \\
Hearth locations: exclusively within dwellings & - & lower or repeated occupations \\
Multi-element sediment signatures: strong, spatially structured enrichments & & \\
\hline \hline
\end{tabular}

TABLE 5. General characteristics of forest, treeline, and tundra camps compared with Ikirahak findings and interpretations. The Ikirahak site shares some characteristics with treeline sites.

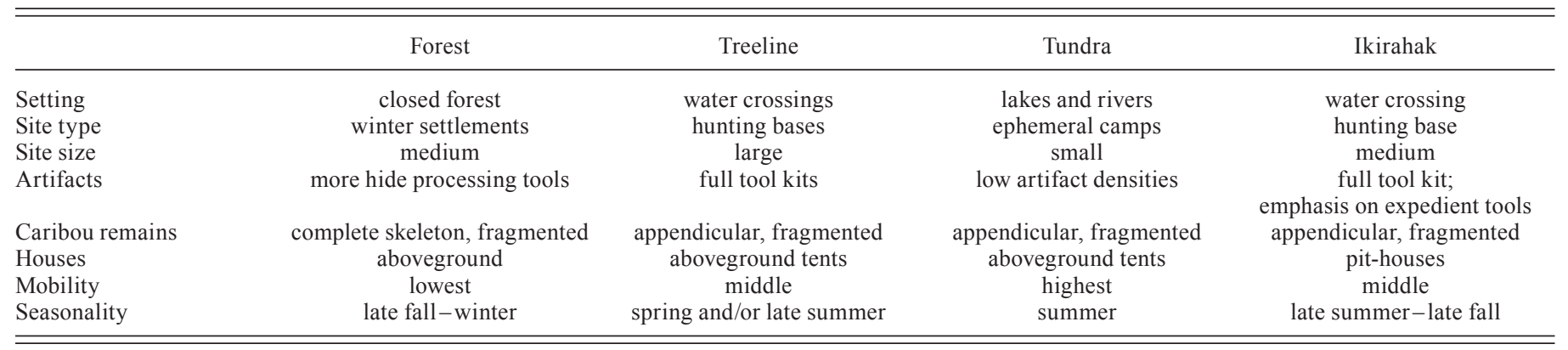

Nonetheless, out findings raise a fundamental question: what factors informed land use decisions at Ikirahak?

Was Ikirahak a land use experiment? Does it represent responses to unexpected caribou windfalls or late migrations, or the ambitions of group leaders to establish new territories? These scenarios may explain single occupations or perhaps even a handful of occupations in very tight succession, but they can not explain the repeated use of the camp over hundreds of years (Fig. 3). Could the use of pit-houses at Ikirahak relate to climate change, specifically shifts toward colder conditions? A warming trend began during the Early Taltheilei period (2450-1800 BP) and reached its height in the Middle period (1800-1300 BP). Since, there have been only minor changes, with the exception of the Little Ice Age ( 650-80 BP) during the latter part of the Late Taltheilei period (1300-300 BP) (Gordon, 1996, 2005). Our radiocarbon dates indicate that pit-houses were used throughout the entire life history of the camp, despite fluctuations in climate (Fig. 3). It is unlikely that the use of pit-houses and the use of this location in general were responses to rapid or gradual climactic changes.

Could people have overwintered at Ikirahak? This is a remote possibility, but it is difficult to conceive of given the shallow depths of the house pits relative to other types of semi-subterranean architecture used in the Arctic (Lee and Reinhardt, 2003). It seems more reasonable, however, that people may have lingered on the tundra into the fall to intercept stragglers from the main caribou herd before moving into the forest for winter (Parker, 1972; Darby, 1978). They likely had social and economic obligations to fulfill, and the larger community surely anticipated their arrival at larger forest camps. They also knew the forest would offer reprieve from the harsh winter conditions they would face on the tundra (Gordon, 1996). During the depth of winter, tundra temperatures drop to $-40^{\circ} \mathrm{C}$ or more with windchill, providing a very good incentive for people to move into the sheltered boreal forest (Thompson, 1968). The forest also provides abundant wood for building dwellings and long-lasting fires.

We hypothesize that Ikirahak was a late summer to fall caribou hunting and processing camp. This scenario is supported by the following site characteristics: (a) the use of pit-house architecture; (b) dwelling maintenance activities; (c) the isolation of tool making activities and hearth features to inside spaces; (d) good representation of tool making and maintenance debitage, expedient tools, and scrapers; (e) an overrepresentation of caribou limb elements, bone fragments (i.e., heavily processed bone), and an absence of high yield units (i.e., axial elements); (f) a preponderance of highly burned bone; and (g) strong, spatially structured multi-element enrichments in open-air spaces.

Given the use of the site across all three Taltheilei periods, a roughly 2000-year timeframe, the site most parsimoniously represents a deeper socio-ecological adaptation rather than immediate or shorter-term reactions to isolated events. Much of what is understood about the Taltheilei culture is based on archaeology conducted 
in the Beverly caribou range (Fig. 1). Land use in this region reflects a widespread adaptation to Beverly herd behaviour (Gordon, 1996). It is possible that what we see at Ikirahak represents a land-use strategy specific to eastern Barrenland Taltheilei groups adapted to Qamanirjuaq herd behaviour in the Maguse Lake area. This local adaptation may have involved a reliance on the Arviat Rankin Inlet sub-herd during late summer to fall hunting expeditions, or waiting out the last of southbound migrants in order to both maximize catches and gather spatiotemporal reconnaissance on the arrival, peak, decline, and absence of herds around Maguse Lake hunting territories.

This raises the question: why did people in the Maguse Lake region of Qamanirjuaq Range linger for a longer period of time on the tundra instead of heading back to the forest before the onset of harsh weather conditions? It seems plausible that the people calling Ikirahak home were attempting to maximize resource acquisition by intercepting herds that were moving south toward their winter territories (Gordon, 1996). Hundreds of caribou were observed at Ikirahak Island water crossings during our late summer fieldwork (Fig. 2c). Similar behaviour in the past would have offered excellent hunting opportunities around Ikirahak. Caribou resources secured during late summer to fall hunts supplemented winter economies. Herds dispersed throughout the forest during winter would have made hunts more unpredictable and expensive in terms of time and labour spent (Gordon, 1996).

Caribou hides were in prime condition by late summer. Summer warble fly damage had healed and hides would have become thicker for the winter months (Oswalt, 1966; Helm and Leacock, 1971; Smith, 1981; Thompson, 1994). By this time of year, caribou had also put on their winter fat, a valuable resource that would have made fall meat more desirable as well (Dauphiné, 1976). Considering these observations, Taltheilei communities at Ikirahak likely aimed to obtain these resources during late summer to fall when herds were moving south for winter. These resources would have had to undergo some degree of processing in order to be efficiently transported south into winter camps. We suggest that Ikirahak was not rapidly abandoned immediately after the hunting season. Carcasses would have been butchered and meat dried, frozen, or prepared in another way. Marrow and fat would have been removed and solidified, and fat and flesh would have been removed from hides to prevent rapid decay (Baillargeon, 2010). We suspect that processing of this nature pushed the time spent at Ikirahak from late summer into the colder part of fall. People consistently anticipated this, and they built pithouses to adapt.

Low amounts of early stage lithic reduction debitage and a predominance of middle and late stage lithic reduction debitage suggest later stage manufacturing and maintenance of hunting gear. Butchering and hide processing at Ikirahak were also suggested by the presence of unifaces, bifaces, expedient tools, scrapers, and abraders. Scrapers were the most abundant artifact type in Houses 2 and 6, the second most abundant in House 3, and the third most abundant in House 8, suggesting hide processing was done at the camp (Table 2). Based on the tools alone, the prevalence of these activities is unclear. However, strong potassium, iron, magnesium, and strontium anomalies detected in several open areas suggest that flesh, fat, bone, and blood derived from processing had a profound, longlasting effect on local sediment chemistry, in turn implying that animal processing was one of the primary work tasks undertaken at the camp (Griffith, 1980, 1981; Knudson et al., 2004; King, 2008; Butler et al., 2018).

The predominance of long bones and highly fragmented bone indicates that marrow extraction was done at the camp. The absence of cranial and axial elements further suggests that initial staging and butchering took place away from the camp (Gordon, 1996). Ribs were absent at site. These high meat-yielding elements were reasonably kept intact and transported elsewhere. These parts were likely brought to forest camps, where axial elements have been recovered (Gordon, 1996). Analogous to the large treeline camps identified at the treeline in the Beverly caribou range, Ikirahak was likely a hunting base camp.

The logistics involved with transporting people and resources off Ikirahak Island and then south also reasonably influenced decisions to stay into the cold season. Historic documents and site distributions tell us that Taltheilei and Chipewyan people traveled along eskers (Gordon, 1996; Friesen, 2004). These routes were likely useful for east-west forays between camps in the Maguse Lake area, while using eskers to travel between the lake and forest required taking an indirect tacking route, adding hundreds of kilometers onto the already lengthy trip south. Such a mode of travel was likely unreasonably time consuming at the end of the fall hunting season when trying to relocate people and supplies.

The distribution of sites in the southerly extent of the Qamanirjuaq Range represents what is currently known of the Taltheilei winter territory in this region (Fig. 1: $d-h$ ). This suspected winter range is located hundreds of kilometers south of Maguse Lake. If people were moving into this range from Maguse Lake for winter, it may have been much more efficient to move the community and resources after freeze-up during late fall. Considering the indirect route dictated by eskers and the difficulty in negotiating bogs, ponds, and gully-pocked landscapes, it was likely much more efficient to sledge equipment and resources toward the forest over frozen landscapes (Fig. 2d). For example, it is known that both the modern Cree of the eastern Subarctic and peoples of historic periods were able to travel efficiently and extensively after bogs, lakes, gullies, and ponds had frozen over (Hanks, 1983). During the late fall and winter, historic period Chipewyan people used frozen caribou skins to sledge equipment around, routing their trips as the crow flies across frozen lakes and rivers (Gordon, 1996; Friesen, 2004). Taltheilei people may have done the same on their trips south from Ikirahak Island. 


\section{SUMMARY AND CONCLUSION}

Taltheilei people spent their summers on the tundra and winters in the forest for over 2000 years (Gordon, 1999, 2005). Our findings at Ikirahak suggest that not all Taltheilei tundra sites are ephemeral camps occupied by small groups of highly mobile people during the height of summer. Late summer to fall was a time dedicated to largescale caribou hunting at water crossings located close to the forest. We propose that people at Ikirahak had the same hunting focus at this time of year, yet their late summer to fall hunting territory was located farther north, far removed from suspected wintering grounds. We have discovered evidence supporting the idea that the Ikirahak site on Maguse Lake was occupied for longer periods of time relative to Taltheilei tundra sites in general, and that these visits extended into the cold fall season. We summarize our findings into eight key points:

1. The presence of pit-house dwellings at Taltheilei sites is extremely rare. Only three of over 700 sites have been identified as pit-house sites. We propose that the people living at Ikirahak invested in building structurally sound pit-houses with internal terracing for longer-term fall occupations.

2. There is evidence for dwelling maintenance. The somewhat larger frequencies of lithic debitage $(<3 \mathrm{~cm})$ around the internal perimeters of dwelling floors are suggestive of floor cleaning. However, this may also relate to scuffing or cleaning prior to reoccupation. The low amount of debitage recovered from House 2 may indicate short-term occupation, or it may represent cleaning. Strong multi-element enrichments recorded adjacent to dwellings are suggestive of hearth cleaning. Such dwelling maintenance chores are common among hunter-gatherer households with lower residential mobility.

3. The lithic assemblage provides somewhat ambiguous evidence for mobility. The amount of debitage recorded may have been produced in a short time. The tool kit represented at Ikirahak was similar to that of Migod, a short-term tundra site. However, Ikirahak has higher numbers of expedient tools and evidence of more bifacial reduction when compared to Migod. Both are suggestive of lower residential mobility at Ikirahak. The abundance of local raw materials used for tool making also provides support for lower residential mobility.

4. There was no indication that the faunal assemblage experienced a serious degree of post-depositional degradation. The prevalence of caribou (artiodactyl) limb elements and absence of cranial and axial elements suggests that initial butchering took place away from the camp, and high yield units were not discarded at the camp. The site appears to have functioned as a hunting and processing base camp.

5. The abundance of highly fragmented caribou bone in the faunal assemblage and element enrichments in open-air spaces suggest that processing was carried out at the camp. The relative frequency of scrapers is further suggestive of hide processing, yet the extent of processing is unclear. Hides and meat were in prime condition during late summer to fall when caribou were aggregated and moving south. We propose that people aimed to intercept herds (possibly straggling sub-herds) returning from summer calving grounds. Necessary processing pushed residence further into the late fall.

6. The abundance of calcined bone fragments and bone ash in dwelling hearth sediments indicates significant bone burning. This implies conservation of wood fuels, in turn suggesting a need to manage fuel sources during longer stays. It may also suggest colder season occupations.

7. Hearths were exclusively established inside dwelling structures, which supports an emphasis on optimizing fuel use, specifically by only using valuable fuels to heat spaces better suited for heat retention. We suspect that this reflects fuel management during longer fall occupations.

8. There was no evidence for the establishment of outdoor lithic workshops. Most debitage was identified around hearths. This suggests that tool making activities were isolated to inside spaces, implying colder season use of the camp.

Longer fall occupations at the Ikirahak site raise questions concerning previously unrecognized diversity in Taltheilei land use. What we are seeing at Ikirahak diverges from patterns documented for the historic period Chipewyan descendents of the Taltheilei, who travelled the tundra in small, highly mobile groups exclusively during the summer. Our findings highlight differences not only between historic period Chipewyan and pre-contact Taltheilei, but also internal diversity among the Taltheilei. We suspect that the colder season use of the tundra and pit-houses is specific to the Maguse Lake area and may represent a unique, localized adaptation to Qamanirjuaq herd behaviour. Our work highlights the need for more research on the Taltheilei culture using contemporary methodologies.

Additional questions are raised that require attention. Are the pit-houses at Ikirahak contemporary? Is this newfound diversity in tundra land-use, particularly the use of pit-houses, truly isolated to the Maguse Lake area? Have other Taltheilei pit-house sites in the Barrenlands been mistakenly attributed to other cultures? Are there examples of Taltheilei pit-house features in other areas of 
the Barrenlands? What methodological approaches and lines of evidence can be tapped to better resolve residential mobility, seasonality, and resource acquisition strategies at Taltheilei pit-house sites?

We propose that research at the other pit-house sites on Maguse Lake should be carried out in order to support or refute our hypotheses concerning mobility, seasonality, and hunting. Approaches such as incremental stable isotope analyses of caribou teeth, examinations of caribou tooth eruption and annulations, juvenile elements, and male to female ratios, and multidisciplinary investigations of openair parts of the sites (e.g., undertaking sediment DNA, blood and fat residues, compound specific isotopes, and bone collagen peptide fingerprints with the aim of identifying diverse facilities such as combustion features, workshops, animal processing areas, middens, and storage features) will contribute to resolving issues while firmly defining seasonality, residential mobility, and hunting strategies at other pit-house sites. Survey work along other major rivers, lakes, and caribou water crossings in the tundra region of the Qamanirjuaq range is also needed in order to confirm whether the Taltheilei use of pit-house encampments is a local innovation isolated to the Maguse Lake region.

\section{ACKNOWLEDGEMENTS}

We thank the Social Sciences and Humanities Research Council of Canada, International Polar Year, Northern Scientific Training Program, Azrieli Foundation, University of Calgary, and University of Haifa for funding the different stages of data collection, synthesis, and presentation of this project. Many thanks are extended to the community of Arviat, our guides, and field crew members. The University of Calgary, Department of Chemistry and Memorial University of Newfoundland, Department of Earth Sciences (TERRA) provided analytical services. We thank three anonymous reviewers and the Editor of Arctic for their helpful comments on an earlier version of our paper.

\section{REFERENCES}

Aldeias, V. 2017. Experimental approaches to archaeological fire features and their behavioral relevance. Current Anthropology 58(S16):S191-S205. https://doi.org/10.1086/691210

Aylsworth, J.M., and Shilts, W.W. 1989. Glacial features around the Keewatin Ice Divide: Districts of Mackenzie and Keewatin. Paper 88-24. Ottawa: Geological Survey of Canada. https://doi.org/10.4095/127320

Baillargeon, M. 2010. North American Aboriginal hide tanning: The act of transformation and revival. Gatineau, Québec: Canadian Museum of Civilization. https://doi.org/10.2307/j.ctv16wb3
Bamforth, D.B., Becker, M., and Hudson, J. 2005. Intrasite spatial analysis, ethnoarchaeology, and Palaeoindian landuse on the Great Plains: The Allen Site. American Antiquity 70(3):561-580. https://doi.org/10.2307/40035314

Bettinger, R.L. 1989. The archaeology of Pinyon House, Two Eagles, and Crater Middens: Three residential sites in Owens Valley, eastern California. Anthropological Papers of the American Museum of Natural History No. 67. New York: AMNH.

Binford LR. 1967. Smudge pits and hide smoking: The use of analogy in archaeological reasoning. American Antiquity 32(1):1-12.

https://doi.org/10.2307/278774

- 1980. Willow smoke and dogs' tails: Hunter-gatherer settlement systems and archaeological site formation. American Antiquity 45(1):4-20. https://doi.org/10.2307/279653

- 1990. Mobility, housing and environment: A comparative study. Journal of Anthropological Research 46(2):119-152. https://doi.org/10.1086/jar.46.2.3630069

Bowyer, R.T., Van Ballenberghe, V., and Kie, J.G. 2003. Moose. In: Feldhamer, G.A., Thompson, B.C, and Chapman, J.A., eds. Wild animals of North America: Biology, management, and conservation, 2nd ed. Baltimore, Maryland: Johns Hopkins University Press. 931-964.

Bryson, R.A., Irving, W.N., and Larsen, J.A. 1965. Radiocarbon and soil evidence of former forest in the southern Canadian tundra. Science 147(3653):46-48. https://doi.org/10.1126/science.147.3653.46

Burch, E.S., Jr., and Blehr, O. 1991. Herd following reconsidered. Current Anthropology 32(4):439-445. https://doi.org/10.1086/203980

Butler, D.H., and Dawson, P.C. 2013. Accessing hunter-gatherer site structures using Fourier transform infrared spectroscopy: Applications at a Taltheilei settlement in the Canadian SubArctic. Journal of Archaeological Science 40(4):1731 - 1742. https://doi.org/10.1016/j.jas.2012.11.015

- 2018. Untangling natural and anthropogenic multielement signatures in archaeological soils at the Ikirahak site, Arctic Canada. Boreas 47(1):189-201. https://doi.org/10.1111/bor.12258

Butler, D.H., Lopez-Forment, A., and Dawson, P.C. 2018. Multielement and biomolecular analyses of soils as a means of sustainable site structure research on hunter-gatherer sites: A case study from the Canadian Arctic. Journal of Archaeological Science: Reports 17:973-999.

https://doi.org/10.1016/j.jasrep.2015.11.030

Canadian Government National Climate Data and Information Archive (CGNCDIA) 2018.

Carr, C. 1984. The nature of organization of intrasite archaeological records and spatial analytic approaches to their investigation. Chapter 3. Advances in Archaeological Method and Theory 7:103-222. https://doi.org/10.1016/B978-0-12-003107-8.50008-6 
Clark, D.W. 2001. Proto-Athapaskan. In: Peregrine, P.N., and Ember, M., eds. Encyclopedia of prehistory. Boston: Springer. $169-178$. https://doi.org/10.1007/978-1-4615-1191-5_21

Cook, D.E., Kovacevich, B., Beach, T., and Bishop, R. 2006. Deciphering the inorganic chemical record of ancient human activity using ICP-MS: A reconnaissance study of Late Classic soil floors at Cancuén, Guatemala. Journal of Archaeological Science 33(5):628-640. https://doi.org/10.1016/j.jas.2005.09.019

Costamagno, S., Griggo, C., and Mourre, V. 1998. Approche expérimentale d'un problème taphonomique: Utilisation de combustible osseux au Paléolithique. Préhistoire Européenne 13:167-194.

Costamagno, S., Théry-Parisot, I., Brugal, J.-P., and Guibert, R. 2005. Taphonomic consequences of the use of bones as fuel. Experimental data and archaeological applications. In: O'Connor, T., ed. Biosphere to lithosphere: New studies in vertebrate taphonomy. Proceedings of the 9th Conference of the International Council of Archaeozoology, Durham, August 2002. Oxford: Oxbow Books. 51-62.

Cowan, F.L. 1999. Making sense of flake scatters: Lithic technological strategies and mobility. American Antiquity 64(4):593-607.

https://doi.org/10.2307/2694207

Darby, W.R. 1978. Beverly and Kaminuriak caribou monitoring and land use controls. Completion Report No. 1. Yellowknife: Wildlife Service, Government of the Northwest Territories.

Dauphiné, T.C. 1976. Biology of the Kaminuriak population of Barren-Ground caribou: Part 4. Growth, reproduction and energy reserves. Canadian Wildlife Service Report Series No. 38. Ottawa: Environment Canada, Wildlife Service.

Dawson, P., Suluk, L., Eastaugh, E., Walls, M., and Hodgetts, L. 2008a. Permit report number 07-004A: A report on archaeological fieldwork undertaken in 2007 at Kuuvik (JiKu-1; JiKu-2). Unpubl. report on file with the Government of Nunavut, PO Box 1000, Station 200, Iqaluit, Nunavut X0A 0A0, Canada.

Dawson, P., Suluk, L., Eastaugh, E., Walls, M., and Hodgetts, L. 2008b. Permit report number 07-005A: A report on archaeological fieldwork undertaken in 2007 at Ikirahak (JjKs-7). Unpubl. report on file with the Government of Nunavut, PO Box 1000, Station 200, Iqaluit, Nunavut X0A 0A0, Canada.

Dawson, P., Pickering, S., McNamee, C., Cyr, H., and Hodgetts, L. 2009. Permit report 2008_023A: A report on archaeological fieldwork at Ikirahak, Maguse Lake, Nunavut. Unpubl. report on file with the Government of Nunavut, PO Box 1000, Station 200, Iqaluit, Nunavut X0A 0A0, Canada.

Dawson, P., Pickering, S., Butler, D., Hodgetts, L., and Suluk, L. 2010. A report on 2009 archaeological excavations carried out at JjKs-7, Maguse Lake, Nunavut. Unpubl. report on file with the Government of Nunavut, PO Box 1000, Station 200, Iqaluit, Nunavut X0A 0A0, Canada.

ECCC (Environment and Climate Change Canada). 2018. 1981-2010 climate normals \& averages.

http://climate.weather.gc.ca/climate_normals/index_e.html
Elliott-Fisk, D.L. 1983. The stability of the northern Canadian tree limit. Annals of the Association of American Geographers 73(4):560-576. https://doi.org/10.1111/j.1467-8306.1983.tb01859.x

Friesen, T.M. 2004. A tale of two settlement patterns: Environmental and cultural determinants of Inuit and Dene site distributions. In: Crothers, G.M., ed. Hunters and gatherers in theory and archaeology. Carbondale, Illinois: Center for Archaeological Investigations, Southern Illinois University. 299-315.

Giddings, J.L. 1956. A flint site in northernmost Manitoba. American Antiquity 21(3):255-268. https://doi.org/10.2307/277197

Gilman, P.A. 1987. Architecture as artifact: Pit structures and pueblos in the American Southwest. American Antiquity 52(3):538-564.

https://doi.org/10.2307/281598

Goldberg, P., Dibble, H., Berna, F., Sandgathe, D., McPherron, S.J.P., and Turq, A. 2012. New evidence on Neandertal use of fire: Examples from Roc De Marsal and Pech De L 'Azé Iv. Quaternary International 247:325-340.

https://doi.org/10.1016/j.quaint.2010.11.015

Gordon, B.H.C. 1975. Of men and herds in Barrenland prehistory. Ottawa: National Museums of Canada. https://doi.org/10.2307/j.ctv1721h

- 1976. Migod - 8,000 years of Barrenland prehistory. Ottawa: National Museums of Canada.

https://doi.org/10.2307/j.ctv16zqv

- 1977a. Chipewyan prehistory. In: Helmer, J.W., Van Dyke, S., and Kense, F.J., eds. Problems in the prehistory of the North American Subarctic: The Athapaskan question. Calgary, Alberta: Archaeological Association, Department of Archaeology, University of Calgary. 72-76.

1977b. Temporal, archaeological, and pedological separation of the Barrenland Arctic Small Tool and Taltheilei Traditions. In: Helmer, J.W., Van Dyke, S., and Kense, F.J., eds. Problems in the prehistory of the North American Subarctic: The Athapaskan question. Calgary, Alberta: Archaeological Association, Department of Archaeology, University of Calgary. 77-82.

- 1981. Man-environment relationships in Barrenland prehistory. Musk-Ox 28:1-19.

- 1990. More on the herd-following hypothesis. Current Anthropology 31(4):399-400. https://doi.org/10.1086/203858

- 1996. People of sunlight, people of starlight: Barrenland archaeology in the Northwest Territories of Canada. Hull, Québec: Canadian Museum of Civilization. https://doi.org/10.2307/j.ctv17560

. 2005. 8000 years of caribou and human seasonal migration in the Canadian Barrenlands. Rangifer 25(4):155 - 162. https://doi.org/10.7557/2.25.4.1780

Griffith, M.A. 1980. A pedological investigation of an archaeological site in Ontario, Canada, I. An examination of the soils in and adjacent to a former village. Geoderma 24(4):327-336.

https://doi.org/10.1016/0016-7061(80)90060-9 
1981. A pedological investigation of an archaeological site in Ontario, Canada, II. Use of chemical data to discriminate features of the Benson Site. Geoderma 25(1-2):27-34. https://doi.org/10.1016/0016-7061(81)90004-5

Grove, M. 2009. Hunter-gatherer movement patterns: Causes and constraints. Journal of Anthropological Archaeology 28(2):222-233.

https://doi.org/10.1016/j.jaa.2009.01.003

Hanks, C.C. 1983. An ethnoarchaeological approach to the seasonality of historic Cree sites in central Québec. Arctic 36(4):350-355.

https://doi.org/10.14430/arctic2289

Hayden, B., and Cannon, A. 1983. Where the garbage goes: Refuse disposal in the Maya Highlands. Journal of Anthropological Archaeology (2):117-163. https://doi.org/10.1016/0278-4165(83)90010-7

Helm, J., and Leacock, E.B. 1971. The hunting tribes of Subarctic Canada. In: Leacock, E.B., and Lurie, N.O., eds. North American Indians in historical perspective. New York: Random House. 343-374.

Hill, M.G., Rapson, D.J., Loebel, T.J., and May, D.W. 2011. Site structure and activity organization at a Late Paleoindian base camp in western Nebraska. American Antiquity 76(4):752 - 772. https://doi.org/10.7183/0002-7316.76.4.752

Hitchock, R.K. 1987. Sedentism and site structure: Organization changes in Kalahari Basarwa residential locations. In: Kent, S., ed. Method and theory for activity area research: An ethnoarcheological approach. New York: Columbia University Press. 374-423.

Hodgetts, L.M., Dawson, P.C., and Eastaugh, E.J.H. 2011. Archaeological magnetometry in an Arctic setting: A case study from Maguse Lake, Nunavut. Journal of Archaeological Science 38(7):1754-1762. https://doi.org/10.1016/j.jas.2011.03.007

Irving, W.N. 1962. A provisional comparison of some Alaskan and Asian stone industries. In: Campbell, J.M., ed. Prehistoric cultural relations between the Arctic and temperate zones of North America. Technical Paper 11. Montreal: Arctic Institute of North America. 55-68.

Janes, R.R. 1989. An ethnoarchaeological model for the identification of prehistoric teepee remains in the boreal forest. Arctic 42(2):128-138. https://doi.org/10.14430/arctic1649

Kedrowski, B.L., Crass, B.A., Behm, J.A., Luetke, J.C., Nichols, A.L., Moreck, A.M., and Holmes, C.E. 2009. GC/MS analysis of fatty acids from ancient hearth residues at the Swan Point archaeological site. Archaeometry 51(1):110-122. https://doi.org/10.1111/j.1475-4754.2008.00384.x

Kelly, R.L. 1983. Hunter-gatherer mobility strategies. Journal of Anthropological Research 39(3):277-306. https://doi.org/10.1086/jar.39.3.3629672

1992. Mobility/sedentism: Concepts, archaeological measures, and effects. Annual Review of Anthropology 21:43-66. https://doi.org/10.1146/annurev.an.21.100192.000355

- 1995. The foraging spectrum: Diversity in hunter-gatherer lifeways. Washington, D.C.: Smithsonian Institution Press.
Kelly, R.L., and Todd, L.C. 1988. Coming into the country: Early Palaeoindian hunting and mobility. American Antiquity 53(2):231 - 244 . https://doi.org/10.2307/281017

Kelly, R.L., Poyer, L., and Tucker, B. 2005. An ethnoarchaeological study of mobility, architectural investment, and food sharing among Madagascar's Mikea. American Anthropologist 107(3):403-416. https://doi.org/10.1525/aa.2005.107.3.403

Kent, S. 1991. The relationship between mobility strategies and site structure. In: Kroll, E.M., and Price, T.D., eds. The interpretation of archaeological spatial patterning. New York: Plenum Press. 33-60. https://doi.org/10.1007/978-1-4899-2602-9_3

King, S.M. 2008. The spatial organization of food sharing in Early Postclassic households: An application of soil chemistry in ancient Oaxaca, Mexico. Journal of Archaeological Science 35(5):1224-1239. https://doi.org/10.1016/j.jas.2007.08.010

Knudson, K.J., Frink, L., Hoffmann, B.W., and Price, T.D. 2004. Chemical characterization of Arctic soils: Activity area analysis in contemporary Yup'ik fish camps using ICP-AES. Journal of Archaeological Science 31(4):443 - 456. https://doi.org/10.1016/j.jas.2003.09.011

Kooyman, B.P. 2000. Understanding stone tools and archaeological sites. Calgary, Alberta: University of Calgary Press; Albuquerque: University of New Mexico Press. https://doi.org/10.2307/j.ctv6gqs13

Lee, H.A. 1968. Quaternary geology. In: Beals, C.S., ed. Science, history, and Hudson Bay. Ottawa: Department of Energy, Mines, and Resources Canada. 503-542.

Lee, M., and Reinhardt, G.A. 2003. Eskimo architecture: Dwelling and structure in the early historic period. Fairbanks: University of Alaska Press.

Le Mouël, J.-F., and Le Mouel, M. 2001. Aspects of Early Thule culture as seen in the architecture of a site on Victoria Island, Amundsen Gulf area. Arctic 55(2):167-189.

https://doi.org/10.14430/arctic701

Linderholm, J. 2007. Soil chemical surveying: A path to a deeper understanding of prehistoric sites and societies in Sweden. Geoarchaeology 22(4):417-438. https://doi.org/10.1002/gea.20159

Lyman, R.L. 1994. Vertebrate taphonomy. Cambridge: Cambridge University Press. https://doi.org/10.1017/CBO9781139878302

MacNeish, R.S. 1951. An archaeological reconnaissance in the Northwest Territories. Annual Report of the National Museum of Canada for the fiscal year 1949-50. Bulletin 123. Ottawa: Department of Resources and Development, National Parks Branch, National Museum of Canada. 24-41.

Magne, M.P.R. 1985. Lithics and livelihood: Stone tool technologies of central and southern interior British Columbia. Ottawa: National Museum of Man. https://doi.org/10.2307/j.ctt22zmdkm

Maxwell, J.B. 1986. A climate overview of the Canadian inland seas. In: Martini, I.P., ed. Canadian inland seas. Amsterdam: Elsevier. 79-100. https://doi.org/10.1016/S0422-9894(08)70898-5 
McGhee, R. 1970. Excavations at Bloody Falls, N.W.T., Canada. Arctic Anthropology 6(2):53-72.

McGuire, R.H., and Schiffer, M.B. 1983. A theory of architectural design. Journal of Anthropological Archaeology 2(3):277-303. https://doi.org/10.1016/0278-4165(83)90002-8

McMartin, I., and Henderson, P.J. 2004. Evidence from Keewatin (Central Nunavut) for paleo-ice divide migration. Géographie physique et Quaternaire 58(2-3):163-186.

https://doi.org/10.7202/013137ar

Mentzer, S.M. 2009. Bone as a fuel source: The effects of initial fragment size distribution. In: Théry-Parisot, I., Costamagno, S., and Henry, A., eds. Gestion des combustibles au paléolithique et au mésolithique: Nouveaux outiles, nouvelles interpretations. Proceedings of the XV World Congress UISPP, 4-9 September 2006, Lisbon, Portugal. BAR International Series 1914. Oxford: Archaeopress. 53-64.

-2014. Microarchaeological approaches to the identification and interpretation of combustion features in prehistoric archaeological sites. Journal of Archaeological Method and Theory 21(3):616-668. https://doi.org/10.1007/s10816-012-9163-2

Middleton, W.D., and Price, T.D. 1996. Identification of activity areas by multi-element characterization of sediments from modern and archaeological house floors using inductively coupled plasma-atomic emission spectroscopy. Journal of Archaeological Science 23(5):673-687.

https://doi.org/10.1006/jasc.1996.0064

Middleton, W.D., Barba, L., Pecci, A., Burton, J.H., Ortiz, A., Salvini, L., and Suárez, R.R. 2010. The study of archaeological floors: Methodological proposal for the analysis of anthropogenic residues by spot tests, ICP-OES, and GC-MS. Journal of Archaeological Method and Theory 17(3):183-208. https://doi.org/10.1007/s10816-010-9088-6

Milek, K.B., and Roberts, H.M. 2013. Integrated geoarchaeological methods for the determination of site activity areas: A study of a Viking Age house in Reykjavik, Iceland. Journal of Archaeological Science 40(4):1845-1865.

https://doi.org/10.1016/j.jas.2012.10.031

Misarti, N., Finney, B.P., and Maschner, H. 2011. Reconstructing site organization in the eastern Aleutian Islands, Alaska using multi-element chemical analysis of soils. Journal of Archaeological Science 38(7):1441 - 1455.

https://doi.org/10.1016/j.jas.2011.02.007

Monks, G.G. 1981. Seasonality studies. In: Schiffer, M.B., ed. Advances in archaeological method and theory, Vol. 4. New York: Academic Press. 177-240. https://doi.org/10.1016/B978-0-12-003104-7.50009-0

Moore, T.R., and Denton, D. 1988. The role of soils in the interpretation of archaeological sites in northern Quebec. In: Bintliff, J.L., Davidson, D.A., and Grant, E.G., eds. Conceptual issues in environmental archaeology. Edinburgh: Edinburgh University Press. 25-37.

Nash, R.J. 1970. The prehistory of northern Manitoba. In: Hlady, W.M., ed. Ten thousand years: Archaeology in Manitoba. Altona: Manitoba Archaeological Society. 76-92.
1975. Archaeological investigations in the traditional forest zone: Northern Manitoba, southern Keewatin, N.W.T. Winnipeg: Manitoba Museum of Man and Nature.

Nichols, H. 1967. The post-glacial history of vegetation and climate at Ennadai Lake, Keewatin, and Lynn Lake, Manitoba (Canada). E\&G Quaternary Science Journal 18(1):176-197. https://doi.org/10.3285/eg.18.1.12

- 1972. A summary of the palynological evidence for late Quaternary vegetational and climatic change in the central and eastern Canadian Arctic. In: Vasari, Y., Hyvärinen, H., and Hicks, S., eds. Climatic changes in Arctic areas during the last ten thousand years. Acta Universitatis Ouluensis: Scientiae rerum naturalium, Oulun Yliopisto, Vol. 3. 309-339.

1976. Historical aspects of the northern Canadian treeline. Arctic 29(1):38-47.

https://doi.org/10.14430/arctic2786

Noble, W.C. 1971. Archaeological surveys and sequences in central District of Mackenzie, N.W.T. Arctic Anthropology 8(1):102-135.

- 1977. The Taltheilei Shale Tradition: An update. In: Helmer, J.W., Van Dyke, S., and Kense, F.J., eds. Problems in the prehistory of the North American Subarctic: The Athapaskan question. Calgary, Alberta: Archaeological Association, Department of Archaeology, University of Calgary. 65-71.

O'Connell, J.F. 1987. Alyawara site structure and its archaeological implications. American Antiquity 52(1):74-108. https://doi.org/10.2307/281061

Oetelaar, G.A. 1993. Identifying site structure in the archaeological record: An Illinois Mississippian example. American Antiquity 58(4):662-687.

https://doi.org/10.2307/282201

- 2000. Beyond activity areas: Structure and symbolism in the organization and use of space inside tipis. Plains Anthropologist 45(171):35-61.

Oetelaar, G.A., and Meyer, D. 2006. Movement and Native American landscapes: A comparative approach. Plains Anthropologist 51(199):355-374.

https://doi.org/10.1179/pan.2006.030

Oswald, D. 1984. The use of site structure to infer social and technological organization from the archaeological record. In: Hall, M., Avery, G., Avery, D.M., Wilson, M.L., and Humphreys, A.J.B., eds. Frontiers: Southern African archaeology today. Cambridge Monographs in African Archaeology No. 10. BAR International Series 207. Oxford: British Archaeological Reports. 297-309.

Oswalt, W.H. 1966. This land was theirs: A study of the North American Indian. New York: John Wiley \& Sons Inc.

Panja, S. 2003. Mobility strategies and site structure: A case study of Inamgaon. Journal of Anthropological Archaeology 22(2): $105-125$.

https://doi.org/10.1016/S0278-4165(03)00005-9

Park, R.W. 1997. Thule winter site demography in the high Arctic. American Antiquity 62(2):273-284.

https://doi.org/10.2307/282510 
Parker, G.R. 1972. Biology of the Kaminuriak population of Barren-ground caribou, Part 1. Canadian Wildlife Service Report Series No. 20. Ottawa: Environment Canada, Wildlife Service.

Petch, V.P. 1992. An archaeological survey of the Thlewiaza River from Fort Hall Lake to Nuellin Lake. Report on file with Manitoba Natural Resources, Parks Branch.

Petch, V.P., Punter, E., Groom, H., Bahr, J., and Wilson, R. 1997. The Robertson Esker in northern Manitoba: A journey through time. Winnipeg, Manitoba: Northern Lights Heritage Services.

Pickering, S. 2012. Taltheilei houses, lithics, and mobility. MA thesis, University of Calgary, Calgary, Alberta. https://doi.org/10.11575/PRISM/27975

Pokotylo, D.L., and Hanks, C.C. 1989. Measuring assemblage variability in curated lithic technologies: An ethnoarchaeological case study from the Mackenzie Basin, Northwest Territories, Canada. In: Amick, D.S., and Mauldin, R.P., eds. Experiments in lithic technology. Oxford: Oxford University Press. 49-68.

Robinson, J.L. 1968. Geography of Hudson Bay: Part 1, regional geography. In: Beals, C.S., ed. Science, history, and Hudson Bay. Ottawa: Department of Energy, Mines, and Resources Canada. 201-235.

Rocek, T.R. 1988. The behavioral and material correlates of site seasonality: Lessons from Navajo ethnoarchaeology. American Antiquity 53(3):523-536.

https://doi.org/10.2307/281215

Rondelli, B., Lancelotti, C., Madella, M., Pecci, A., Balbo, A., Pérez, J.R., Inserra, F., Gadekar, C., Ontiveros, M.Á.C., and Ajithprasad, P. 2014. Anthropic activity markers and spatial variability: An ethnoarchaeological experiment in a domestic unit of northern Gujarat (India). Journal of Archaeological Science 41:482-492. https://doi.org/10.1016/j.jas.2013.09.008

Schiegl, S., Goldberg, P., Pfretzschner, H.-U., and Conard, N.J. 2003. Paleolithic burnt bone horizons from the Swabian Jura: Distinguishing between in situ fireplaces and dumping areas. Geoarchaeology 18(5):541-565. https://doi.org/10.1002/gea.10080

Schwimmer, B., Petch, V., and Larcombe, L. 1998. Taltheilei culture 750 B.C.-A.D. 1000. Winnipeg: Manitoba Archaeological Society.

http://www.umanitoba.ca/faculties/arts/anthropology/ manarchnet/chronology/taltheilei/index.html

Shott, M. 1986. Technological organization and settlement mobility: An ethnographic examination. Journal of Anthropological Research 42(1):15-51. https://doi.org/10.1086/jar.42.1.3630378

Simms, S.R. 1989. The structure of the Bustos Wickiup site, Eastern Nevada. Journal of California and Great Basin Anthropology 11(1):2-34.

Smith, J.G.E. 1981. Chipewyan, Cree and Inuit relations west of Hudson Bay, 1714-1955. Ethnohistory 28(2):133 - 156. https://doi.org/10.2307/481115
Sorenson, C.J., Knox, J.C., Larsen, J.A., and Bryson, R.A. 1971. Paleosols and the forest border in Keewatin, N.W.T. Quaternary Research 1(4):468-473. https://doi.org/10.1016/0033-5894(71)90059-7

Stevenson, M.G. 1985. The formations of artifact assemblages at workshop/habitation sites: Models from Peace Point in northern Alberta. American Antiquity 50(1):63-81. https://doi.org/10.2307/280634

2. 1991. Beyond the formation of hearth-associated artifact assemblages. In: Kroll, E.M., and Price, T.D., eds The interpretation of archaeological spatial patterning. New York: Plenum Press. 269-299. https://doi.org/10.1007/978-1-4899-2602-9_10

Stiner, M.C., Kuhn, S.L., Weiner, S., and Bar-Yosef, O. 1995. Differential burning, recrystallization, and fragmentation of archaeological bone. Journal of Archaeological Science 22(2):223-237.

https://doi.org/10.1006/jasc.1995.0024

Théry-Parisot, I. 2002. Fuel management (bone and wood) during the Lower Aurignacian in the Pataud rock shelter (Lower Palaeolithic, Les Eyzies de Tayac, Dordogne, France). Contribution of experimentation. Journal of Archaeological Science 29(12):1415-1421.

https://doi.org/10.1006/jasc.2001.0781

Théry-Parisot, I., and Costamagno, S. 2005. Propriétés combustibles des ossements: Données expérimentales et réflexions archéologiques sur leur emploi dans les sites paléolithiques. Gallia Préhistoire 47(1):235-254.

https://doi.org/10.3406/galip.2005.2051

Thompson, H.A. 1968. Climate. In: Beals, C.S., ed. Science, history, and Hudson Bay. Ottawa: Department of Energy, Mines, and Resources Canada. 263-286.

Thompson, J. 1994. From the land: Two hundred years of Dene clothing. Hull: Canadian Museum of Civilization.

Wells, E.C. 2004. Investigating activity patterns in prehispanic plazas: Weak acid-extraction ICP-AES analysis of anthrosols at Classic Period El Coyote, northeastern Honduras. Archaeometry 46(1):67-84. https://doi.org/10.1111/j.1475-4754.2004.00144.x

USCUOM (Underground Space Center University of Minnesota) 1979. Earth sheltered housing design: Guidelines, examples, and references. New York: Van Nostrand Reinhold.

Wilson, C.A., Davidson, D.A., and Cresser, M.S. 2008. Multielement soil analysis: An assessment of its potential as an aid to archaeological interpretation. Journal of Archaeological Science 35(2):412-424. https://doi.org/10.1016/j.jas.2007.04.006

Wright, J.V. 1975. The prehistory of Lake Athabasca: An initial statement. Ottawa: National Museum of Man. https://doi.org/10.2307/j.ctv1706x

Yellen, J.E. 1977. Archaeological approaches to the present: Models for reconstructing the past. New York: Academic Press. 